\title{
Contributions to the Life-history of Tetraclinis articu- lata, Masters, with some Notes on the Phylogeny of the Cupressoïdeae and Callitroïdeae.
}

BY

\author{
W. T. SAXTON, M.A., F.L.S., \\ Professor of Botany at the Ahmedabad Institute of Science, India.
}

With Plates XLIV-XLVI and nine Figures in the Text.

\section{INTRODUCTION.}

$\mathrm{T}$

HE Gum Sandarach tree of Morocco and Algeria has been well known

to botanists from very early times. Some account of it is given by Hooker and Ball (20), who speak of the beauty and durability of the wood, and state that they consider the tree to be probably correctly identified

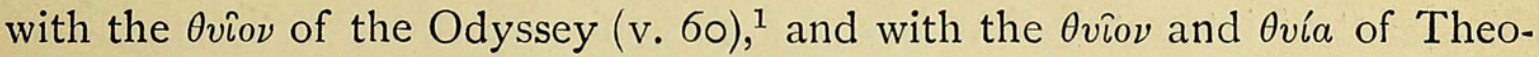
phrastus ('Hist. Pl.' v. 3, 7), ${ }^{1}$ as well as, undoubtedly, with the Citrus wood of the Romans. The largest trees met with by them, growing in an uncultivated state, were about 30 feet high. The resin, known as sandarach, is stated to be collected by the Moors and exported to Europe, where it is used as a varnish. They quote Shaw ( $49 a$ and $b)$ as having described and figured the tree under the name of Thuja articulata, in his 'Travels in Barbary'; this statement, however, is not accurate. In both editions of the work cited the plant is figured and described as 'Cupressus fructu quadrivalvi, foliis Equiseti instar articulatis'.

Some interesting particulars of the use of the timber are given by Hansen (19), who also implies that the embryo has from three to six cotyledons.

Both Hooker and Ball, and Hansen, followed by almost all others who have studied the plant, speak of it as Callitris quadrivalvis.

Masters (31) first distinguished it generically in 1893 , on account of the well-marked differences which it presents, in the external characters of the foliage and branches, from all the species of Callitris. The name Tetraclinis

1 The two references quoted have been corrected from those given by Hooker and Ball, which are inaccurate in both cases.

[Annals of Botany, Vol. XXVII. No. CVIII. October, 1913.] 
has, however, not been taken up (with two or three exceptions) by later investigators, although in external features it resembles Widdringtonia far more closely than Callitris, and if external characters were alone to be used as the criterion, it ought rather to be placed in the former genus than the latter. Dr. C. E. Moss informs me that the plant is known to the Forestry officials in Algeria as Tetraclinis.

Several investigators have studied some points in the morphology. Strasburger (52) describes and figures immature archegonia as being precisely like those of all other Cupressoïdeae, the number of archegonia being given as 'fifteen or more'. Eichler (14) figures the external features of strobili and foliage. Goebel (18) gives figures of the young female strobilus and of a longitudinal section of the ovule.

More interesting, though less precise, are the observations recorded by Juel (21), who unfortunately, however, gives no figures. He reports that the ovules were rather large, and that most of them were empty and shrivelled; others were found to contain a normal endosperm, but no trace of archegonia, nor even of any space or disorganized part; even when archegonia were present, they were never normal, but sometimes had the typical terminal group as well as a smaller similar group at the side of the endosperm. It is not entirely clear what is here meant by 'normal'; if it means the typical archegonial complex of the Cupressoïdeae, as would seem probable, my own results are in direct conflict with those of Juel, but the chief point of interest is that lateral archegonia are stated to occur, either with or without the ordinary terminal group.

Norén $(37$, p. $3 \mathrm{I})$, in a footnote, makes a similar observation: ' In den Präparaten von Callitris quadrivalvis, die ich zu untersuchen Gelegenheit hatte, waren oft mehrere Archegoniengruppen vorhanden. Dies ist aber wahrscheinlich eine abnorme Erscheinung, vielleicht hervorgerufen durch die Kultur im Gewächshause, wo sich der Baum befand, der das Material geliefert hat.' It is doubtful, however, whether the abnormality is wholly due to the effect of cultural conditions; reference will be made to this point later.

The idea was prevalent at one time that this plant was the type species of the genus Callitris; Baker and Smith (3), however, consider that the type was one of the Australian plants included in the genus Callitris, though they were not able to express any very firm opinion as to which species was the first to be so named (probably C. rhomboidea). They follow Masters in excluding Tetraclinis (and Widdringtonia) from the genus, and even if it should prove that this plant was the original type of Callitris, the international rules require that the latter name shall be kept for the greater number of species, in the event of the genus being split. By the same code of rules it is clear that the correct specific name of the plant would be articulata, so that Masters's name, Tetraclinis articulata, is entirely valid. 
Tetraclinis articulata is a tree forming forests of considerable extent in the mountains of Northern Africa, especially in Algeria and Morocco.

The maximum height is given by Hooker and Ball (loc. cit.) as 30 feet, and by Engler (15) as Io metres, but Dr. Moss informs me that the tree reaches a height of about 40 feet, half that height being typical of average trees.

The material used in the present investigation was obtained from a single tree about 20 feet high, growing in the grounds of the South African Museum, Cape Town. I am glad to take this opportunity of thanking Dr. L. Péringuey, Director of the Museum, for his permission to collect the cones at frequent intervals. The origin of the tree in the South African Museum grounds is not certainly known, but it is believed to have been introduced there about 1840 , along with a number of other exotic trees of similar age.

The fixing fluids employed have been (i) Chromosmacetic acid, and (ii) Picric-corrosive sublimate-acetic. For certain stages the former proved most satisfactory, while in other cases the latter was decidedly superior. The methods employed in embedding, \&c., have been the same as those used in the study of Actinostrobus (47). The triple stain has been used throughout, but for the cytological details of the meiotic divisions a duplicate series has been prepared with Heidenhain's haematoxylin.

\section{The Microsporangiate Strobilus and Microsporogenesis.}

The male cones, before the final elongation which separates the sporophylls, are 5-6 $\mathrm{mm}$. long. The sporophylls, as in Widdringtonia (Saxton (44 and 45)), are more or less peltate and bear four microsporangia on the proximal side of the stalk. They are arranged in decussate pairs. The final elongation results in an increase of about 65 per cent. in length. The following are averages of measurements of well-grown cones :

Length of cones before extension, $5.72 \mathrm{~mm}$.

Length of cones after extension, $9 \cdot 43 \mathrm{~mm}$.

The microsporangia are exactly similar to those of other Cupressoïdeae. In the young sporangium there are three layers of cells outside the spore mother-cells, of which the outermost is the epidermis and persists as the mature wall, while the two inner are derived by the division of a single hypodermal layer which is part of the sporogenous tissue and which functions as a tapetum.

In some ways the male cones of Tetraclinis have proved very well suited to a cytological investigation. A good range of stages is found in a single cone, and some variation in a single sporangium; cones of the right age are very easily collected for a number of days, as they do not all develop simultaneously; and cones of such an age are moderately easy to 
fix and embed satisfactorily. On the other hand, the nuclei are somewhat small (though slightly larger than in the Callitroideae); and the large amount of starch present in the later stages of the meiotic divisions is apt sometimes to obscure the cytological details.

The resting nucleus (Pl. XLIV, Fig. I) appears practically identical in structure with that figured by various investigators in other pollen mothercells. There is a network of anastomosing linin threads with numerous rather conspicuous chromatin granules, and a large nucleolus which can usually be seen in optical section to be hollow. No starch is visible. As the nucleus prepares for synapsis, the linin thread thickens to form a deeply staining slender spireme (Fig. 2). This spireme is not one single coiled continuous thread without anastomoses, but can be clearly seen to branch at certain points. Isolated starch grains now appear in the cytoplasm. Then the mesh begins to contract to one side of the nuclear cavity (Fig. 3), this being quickly followed by complete synapsis (Fig. 4). In Tetraclinis, as these figures demonstrate, there is no approach whatever to the condition claimed by Lawson (28) to be characteristic of synapsis. According to that author synapsis consists in an expansion of the nuclear cavity, and not in a contraction of the contents, but even his own figures, as mentioned in a criticism by Professor Farmer, do not support his contention. It may be mentioned, however, that an enlargement of the whole nucleus does occur in Tetraclinis about the time of recovery from synapsis.

As far as can be estimated the nuclei remain for some time in this contracted condition, practically no structure being visible. As recovery begins to set in, loops may sometimes be seen projecting from the periphery of the contracted mass (Fig. 5). Very soon recovery is complete, a very slender spireme being formed (Fig. 6), in which fewer anastomoses can be seen than before contraction. This spireme gradually thickens and shortens (Fig. 7), and at the same time the number of anastomoses becomes less, though it does not appear as though the thread ever becomes entirely free from branching. Up to this time no trace whatever has been seen of any splitting of the thread, such as occurs regularly in some angiospermous pollen mother-cells at this time. Traces of the same splitting have been claimed by Lewis (29) in Pinus and Thuja, and by Miss Ferguson in Pinus.

The stage following (Fig. 8) is that sometimes called the second contraction figure (Farmer and Moore (16), Mottier (33)), but in Tetraclinis no real contraction occurs so far as can be seen. This figure is of interest as showing the only phenomenon which could be interpreted as splitting: of the thread, though such an appearance is probably due merely to the approximation of the two sides of a loop.

Next the thread breaks up to form about a dozen bivalent chromosomes, and these soon shorten and thicken to form the curved bodies seen in Fig. 9. The earliest stages of spindle formation have not been seen distinctly in 
Tetraclinis, but a spindle becomes obvious about the time when the spireme segments, and on it the chromosomes arrange themselves, and, breaking up, begin to move towards the poles (Figs. IO, II, I2). The chromosomes apparently become split at this time, since more than twelve may be counted in polar view (Figs. I3 and I5) passing to the pole, at about the stage of Figs. I2 and I4. This point will be discussed below. The chromosomes on arrival at the pole first form a rather ragged and deeply staining lump (Fig. 16), which soon opens out to form a well-defined daughter nucleus (Figs. I 7 and I 8). No trace of a cell-wall, either permanent or transitory, is seen at any time between the two daughter nuclei. The next figure (Fig. I9) shows a stage which does not appear to agree with that described for other plants. A spireme is organized and at once splits up, before any spindle is recognizable, into about twenty-four chromosomes (i. e. the $2 x$ number) and these become oriented on the spindle, when the latter becomes visible, and, without any division or split in individual chromosomes, separate into two groups of about twelve V-shaped rods, which pass to the poles in the usual way (Figs. 20 and 2I). It is worthy of mention that the two spindles of the 'homotype' division are invariably at right angles to one another, never parallel, as is said to be the case sometimes in other genera.

As the four resulting nuclei reorganize, the spindles of the homotype division disappear entirely, giving the structure shown in Fig. 22. From this stage to the formation of the spores has been followed very carefully, in view of conflicting statements in other genera as to whether or not the mother-cell becomes chambered, and the stages obtained here suggest a possible explanation of those statements. In Tetraclinis no trace whatever of spindle fibres is found between the stages shown in Figs. 22 and 23 respectively, but the cytoplasm cleaves into four equal parts, leaving between them a trace of residual cytoplasm. This residual cytoplasm is not always seen, but would probably be very quickly absorbed in the formation of the wall which is now laid down on each of the four microspores.

In Funiperus, Norén (37) states that the four spores are formed in an unpartitioned mother-cell, but does not mention seeing any residual protoplasm. Nichols (36), working on the same genus, maintains that the mother-cell becomes partitioned, as in Pimus, though the partition walls are not easy to demonstrate satisfactorily. It appears possible that what was seen by Nichols was the residual protoplasm. In preparations showing less contraction from the mother-cell wall than that seen in Fig. 23 , it would be quite possible to interpret the appearance as due to very faintly staining partition walls, but if these were really walls one would certainly expect the cytoplasm to contract away from them, which is obviously not the case here. It is perhaps worth stating that although the phenomena just described can be successfully demonstrated in a good triple-stained Canadabalsam mount, yet they can be seen much more readily after the violet and 
before the orange, with the sections mounted in water. Under these conditions what can otherwise only be seen with difficulty becomes entirely obvious. I have on several occasions (in fact each time cones have been fixed for stages of microsporogenesis) teased out fresh material in acetic methyl green; in this way it can be most clearly shown that the spores lie freely inside the thin wall of the mother-cell. Fig. 24 is drawn from such fresh material (to a smaller scale than the other figures). I think there can be no doubt whatever that in Tetraclinis the mother-cell does not at any time become partitioned.

It may be of interest to review the situation in other Gymnosperms in regard to this point. In the Cycads investigated (Juranyi (22), Treub (56), and Smith (50)), and in Ginkgo (Sprecher (51)), the mother-cell is chambered, the partition walls being thick and persistent. In regard to Ginkgo Sprecher remarks : 'Chaque cellule fille ou grain de pollen (microspore) aura sa propre membrane, puisque si on écrase un tétrasporange, les microspores s'en échappent et laissent la membrane de la cellule mère (Fig. I $82, g$ et $h$ ).' The figures to which he refers show the partitioned mother-cell with thick walls, very similar to those of Cycads.

In Pinus, according to Miss Ferguson (17), the mother-cell is partitioned in a somewhat similar manner. In Araucaria, Burlingame (5) leads one to suppose that the cell is not partitioned, but neither his description nor his figures are explicit on this point. In Thija, Land's (24) figures imply an unpartitioned mother-cell, as is also claimed for Funiperus, as mentioned above, by Norén (37), with whose results Nichols (36) is not in agreement. In Cunninghamia, Miyake (32) reports a chambered mother-cell, but his account appears to suggest a slightly different type to that found in other genera. In Torreya, Robertson's (42) figures imply an absence of chambering. The writer has examined three other genera of Conifers in regard to this point, of which two, Actinostrobus (47) and Cupressus, showed the spores free in the mother-cell, while the third, Callitris, showed thick partition walls, more like those figured in Gnetum africanum (see below) than the figures of any other genus of Conifers.

In the Gnetales, Ephedra (Land (25)) and Welwitschia (Pearson (39)) are not chambered, while Gnetum africanum and G. scandens (Pearson (41)) show thick partition walls, probably of a mucilaginous nature, though in other species of the genus the mother-cells are said not to be chambered.

It is obvious that if all, or even the large majority, of these observations are accepted as correct, then the character is one which cannot, on any scheme of Gymnosperm classification, be of any phylogenetic importance.

Shortly after the formation of the microspores, the mother-cell wall degenerates and disappears entirely, and the wall of the young microspore begins to thicken. Very soon two layers can be recognized in the wall 
(Fig. 25), of which the outer (exospore) possesses some small and inconspicuous projections. This point is of some interest in comparison with the megaspore membrane, as described below.

A nearly mature pollen-grain is shown in Fig. 26. The nucleus always occupies a position to one side of the spore (that next the periphery of the old mother-cell wall) and is always surrounded by a single layer of large and conspicuous starch grains.

No further nuclear change takes place till after pollination, the pollengrain being uninucleate when first seen on the nucellus, as in Funiperus, Cupressus, and Taxus (Coker (10), Nichols (36)), and the Callitroïdeae (Saxton (44-47)). When the ripe fresh pollen is mounted in water and at once examined, it is seen that the wall is comparatively thin, but after a few minutes the exospore usually bursts, owing to the considerable swelling which takes place in the endospore, the latter becoming very much thicker than it was before. It was found that fixing agents had somewhat the same effect on the wall, though to a less extent. Thus an examination of fixed material alone leads to erroneous ideas of the thickness of the wall: the very thick wall described by the writer in Widdringtonia and Callitris was undoubtedly caused partly in this way, though a comparison with similarly fixed material of Tetraclinis indicates that the wall is somewhat thicker in the former genera, which would probably imply its greater thickness in an unswollen condition also.

Some points may here be discussed in connexion with the meiotic divisions. One difficulty, which commonly occurs in the investigation of microsporogenesis, was almost absent in the present case, namely, the sequence of the different stages. There were here three separate characters, which, taken together, made it clear which of any two stages preceded the other, at least in the earlier phases, in which alone difficulties of this sort arise. (i) The position in the cone. In Tetraclinis the youngest sporangia are found always at the apex of the cone, successively older ones appearing below until about the last whorl of sporophylls (or sometimes the last two whorls), which bear somewhat younger sporangia than those immediately above them, but still older than those at the apex. In Funiperus, according to Nichols (36), the sporangia at the apex are more developed than those at the base, contrary to the condition in Tetraclinis. Within a single sporangium some variation occurs, so that the development from the apex to near the base of the cone is not always reliable, without supplementary evidence, in fixing the sequence, though it does make it possible to distinguish, e.g., stages immediately preceding synapsis from those immediately following it. (ii) The degree of separation of the mother-cells. In the stage shown in Fig. I the spore mother-cells form a compact tissue ; shortly after this they begin to show signs of separation, the actual separation and rounding out being completed during synapsis. 
This provides a reliable means of distinguishing nuclei just beginning to contract from those recovering from synapsis, and makes it impossible to confuse pre-synaptic with post-synaptic phases. (iii) In addition to the two points noted above there is a progressive increase in starch content throughout the prophases of the heterotypic division. In the figures no attempt has been made to show with absolute accuracy the position of every starch grain in the section figured, but a few grains have been accurately drawn in with the camera lucida in each case, and, the distribution being very uniform, the rest added free-hand.

Careful search was made, both before and after synapsis, for any indication of such a 'pairing of the spiremes' as is claimed by Overton (38) for various Angiosperms, and by Nichols (36) for Funiperus, but no trace of such a thing was seen. Nor was any distinct evidence forthcoming for the longitudinal splitting of the post-synaptic spireme which appears certainly to occur in many plants, especially Monocotyledons (Farmer and Moore (16), Mottier (33, 34), \&c.), and has been described by Lewis (29) in Pimus and Thija. Miss Ferguson (17) gives a somewhat different explanation of the phenomena in Pinus, maintaining that the splitting, which she also describes in the spireme stage, culminates in the longitudinal splitting of the chromosomes in the first (heterotype) division; the other authors quoted believe that it does not reappear until the splitting of the chromosomes which they describe in the second (homotype) division.

Repeated search was made in Tetraclinis for any signs of transient splitting in the prophases of the heterotype division, and the only stage which could possibly be interpreted as such was that shown in Fig. 8, while even here it seems far more likely that the appearance is caused by the close approximation of the sides of a number of loops.

There does not seem to be any especial reason why splitting should occur at this time, only to disappear again later, and to the writer it seems reasonable to suppose that the differences reported in this respect may be due to real differences between one plant and another, and not, as is often thought, to differences in methods of investigation.

Repeated counts of chromosomes, chiefly in polar views of telophases of the homotype division, gave twelve or thirteen as the $x$ number of chromosomes. Less conclusive evidence was obtained as to the $2 x$ number, owing to the difficulty of counting the larger number of chromosomes in nuclei as small as those of Tetraclinis, but the few counts which were made indicated twenty-four as the probable figure. The case shown in Fig. I 3 is difficult to interpret; it is a very clear polar view, showing the ends of the chromosomes passing to the poles at the heterotype division. Thirty-two of these ends can be counted quite clearly; if the chromosomes are all $\mathrm{V}$-shaped this would correspond to sixteen whole chromosomes; comparison with Fig. I I, however, suggests a quite possible explanation, 
namely, that some are straight and some bent into a $\mathrm{V}$-shape. If we assume, as would appear to be the case, that the chromosomes have split after passing away from the equator, as in many other plants, then the twenty-four would be accounted for if sixteen of them were straight and the other eight $\mathrm{V}$-shaped. I can suggest no other explanation which appears in any way satisfactory, and which is at the same time not contrary to all accepted views in regard to chromosome numbers as seen during the meiotic phase.

Nichols (36) maintains that after synapsis there are no parts of the spireme which meet and fuse, that is, no anastomosing; the spireme is one continuous thread. Norén, on the contrary, considers that anastomoses do occur, as is also said to be the case in Pinus (Ferguson (17)). In Tetraclinis there is no doubt whatever that anastomoses do occur in the post-synaptic spireme. They are most clearly seen where only a small part of the nucleus is cut off in a section; in thicker sections it is difficult to distinguish clearly between a real branching (anastomosing) of the thread, and the case where one part of the thread crosses just below or above another part. At the same time it is evident that there is much less anastomosing after synapsis than there was before.

The only other point worthy of special mention is the complete absence of any trace of fibres prior to the cleavage of the contents of the mother-cell into spores. In Funiperus, Nichols (36) gives a figure showing more conspicuous fibres at this time than at any other stage of the meiotic divisions, and they have been described and figured in most other cases where this phase has been investigated. As their absence here appears a distinctly unusual feature, it may be worth mentioning that the regular arrangement of the starch grains almost entirely precludes the possibility of such fibres being present, even on the supposition that the methods of fixing and staining were not sufficiently good to demonstrate them visibly in any one of the numerous preparations showing this stage; as a matter of fact the fixing and staining appeared entirely satisfactory in many cases. A comparison of Fig. I7 with Figs. 22 and 23 will explain what is meant in regard to the starch grains. In Fig. 17 these are arranged in rather definite rows, and are somewhat elongated in the direction of the fibres, as though compressed by the latter, while nothing of the kind is visible in any of the hundreds of cells examined in stages similar to Figs. 22 and 23 .

The Male Gametophyte.

When pollination takes place the grains usually lodge on the edge of the crater-like apex of the nucellus, and the tube grows into the central collapsed area, and then turns downwards. The earliest stage seen after 
the pollen-tube has begun to penetrate the apex of the nucellus (Fig. 27) shows the tube nucleus and the generative cell still enclosed in the spore cavity, the generative ceil being still attached to the spore wall. A somewhat later stage (Fig. 28) shows the tube nucleus some way down the tube, and the generative cell lying free in the spore cavity. Shortly after, the upper part of the tube is found to be empty, while three nuclei, embedded in a common mass of cytoplasm, are found close to its tip. The sterile nuclei (tube and stalk nuclei) are exactly alike, and lie, as usual, side by side, and in advance of the body nucleus (Fig. 29). The body nucleus gradually increases in size, and a part of the cytoplasm soon becomes differentiated around it to form a definite body-cell (Fig. 30). Finally, the body-cell divides to form two hemispherical male cells. Whether these were enclosed in a mother-cell wall could not be determined. Some aspects of the mature pollen-tube are shown in Pl. XLV, Figs. 4I, 42, and Pl. XLVI, Fig. 64. It is worth noting that the two male cells may be placed either side by side or one vertically above the other (Figs. $4 \mathrm{I}$ and 64 ), the former being the usual arrangement in the Cupressoïdeae. There is some evidence that the male cells do not always become spherical when mature, as they usually do in Cupressoïdeae; at any rate a male cell which is still hemispherical has been seen inside an archegonium, and no case has been seen where it could be stated with any certainty that the male cells were spherical in the pollen-tube. ${ }^{1}$

\section{The Megasporangiate Strobilus and the Female Gametophyte.}

The young female cones of Tetraclinis are very similar to those of Widdringtonia, especially $W$. juniperoides, as shown in Text-fig. I. They

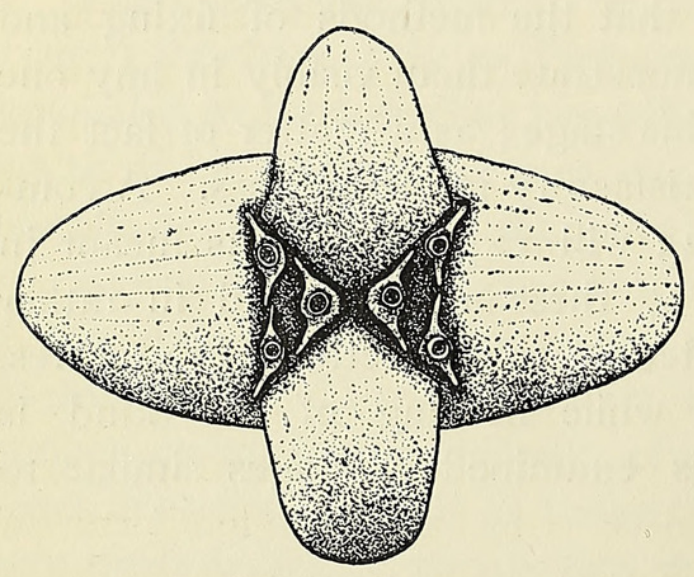

TeXT-FIg. I.-Drawing of a young cone of Tetraclinis as seen from above. $\times$ I 5 . April 24. are borne singly on very short lateral branches, and each consists of two pairs of widely spreading cone scales. In the centre of the cone are seen six (rarely four or eight) erect ovules, with rather long tubular micropyles. The insertion of one pair of scales is slightly below that of the other, and the scales of the upper pair are usually sterile, all the ovules being attached to the two lower scales; when, however, eight ovules are present, two of them are inserted on the upper pair.

A median longitudinal section of

1 Some cases of male cells circular in section have been seen, where the two were cut successively in serial sections, but such an appearance is also characteristic of hemispherical cells, when cut more or less parallel to the flat side. 
the ovule when nearly ready for pollination (Figs. 3I and 59) bears a considerable resemblance to that of other Cupressoideae. There is a long and widely open micropyle, of which the inner cells are quite distinct from the rest as the micropyle closing cells. At the apex of the nucellus a few cells have begun to collapse, a phenomenon which becomes more noticeable after pollination, and which apparently facilitates the penetration of the pollen-tube. According to Tison (55), however, the destruction of the apical cells is primarily brought about in the formation of the "pollination drop'. He remarks: 'Cette production de la gouttelette est accompagnée de la destruction des cellules nucellaires productrices'; this, it may be pointed out, is not the case in the Callitroïdeae, where the 'gouttelettes' have been seen in Actinostrobus and Widdringtonia (Saxton (47)), since in that sub-family the cells at the apex of the nucellus remain intact (except where broken down by an advancing pollen-tube). This would appear to constitute another distinction, though probably not one of any great importance, between Callitroïdeae and Cupressoïdeae ; the observations relative to this point in the Cupressoïdeae (Tison (55), Miyake (32), Nichols (36)) suggest a probability that the formation of a saucer-shaped depression at the apex of the nucellus will be found to be characteristic of all the genera.

At the base of the nucellus is a group of sporogenous cells (shown on a larger scale in Fig. 32), of which about eight to twelve may be seen in median section (either longitudinal or transverse). At this time there is not a very sharp boundary line between sporogenous and non-sporogenous tissue, but at a somewhat later stage the differentiation is more marked (see Fig. 36). The cells of this sporogenous tissue are those figured as such by Goebel (18), and it is quite clear that one of their number is the functional megaspore mother-cell, while the remainder are also morphologically spore mother-cells, which function as a tapetum (spongy tissue).

Fig. 33 shows the apex of the nucellus, in an average ovule, at about the time of pollination. The apical depression is evidently formed by the breaking down of certain cells, and is similar to, but perhaps a trifle deeper than, that usually found in Cupressoïdeae. Fig. 34 shows in outline the apex of another nucellus with a very similar depression, and, above, the micropyle completely closed by the ingrowth of the innermost cells of the integument in that region. Thus a sub-spherical and completely enclosed cavity is formed in which conditions are doubtless very suitable for the germination of the pollen-grain. A transverse section of the closed micropyle is shown in Fig. 35 .

For a short time before dividing the functional mother-cell becomes distinguishable from its neighbours, as shown in Fig. 36 , by the greater size of both cell and nucleus. A few starch grains can also be seen in the rather 
scanty cytoplasm of the cell. At a slightly later stage a single functional megaspore is found (Fig. 37) lying just below two deeply staining and abortive nuclei. These three have evidently been derived from the mothercell. The microphotograph (Fig. 60) shows one of the two sections from which Fig. 37 was drawn. The second abortive nucleus appears in the next section. It will be noticed that the megaspore nuclei are much smaller than those of the surrounding tapetal cells. No stages between Figs. $3^{6}$ and 37 were secured ; they would not be likely to show any marked divergences from the sequence of megasporogenesis as described by Norén (37) and Nichols (36) for Funiperus, by Knischewsky (23) for Thuja, by Coker (9) for Taxodium, and by Miyake (32) for Cunninghamia. Lawson (26 and 27) seems to have obtained only scattered stages in Cryptomeria and Libocedrus, and it is not clear in either case from his figures that the cells named megaspores are really such. It seems just as likely that they may represent a group of megaspore mother-cells similar to that figured in other Cupressoïdeae.

If Lawson's explanation of his figures is correct, it is clear that Cryptomeria and Libocedrus differ widely from all other investigated Cupressoïdeae in this respect; since, however, the figures as published would bear another interpretation, namely, that the earlier stage was archesporium and the later one a group of megaspore mother-cells precisely similar to that found in the other genera, which agree very closely with one another, one is tempted to believe that Lawson has fallen into the error of mistaking mother-cells for spores. A re-examination of Libocedrus and Cryptomeria is certainly desirable in order to settle this point.

The free nuclear divisions in the young prothallus are at first simultaneous (Fig. $3^{8}$ shows one of the thirty-two dividing nuclei met with at the sixth mitosis), but whether these strictly simultaneous divisions occur later has not been determined.

Late stages of the hollow embryo-sac, shortly before the commencement of cell-formation, reveal an important difference between Tetraclinis and the Callitroïdeae ; in the latter the prothallus is narrow and pointed at the apex, and the pollen-tube more or less overlaps its tip some time before cell-formation begins; in Tetraclinis, on the other hand, the apex of the young prothallus is quite truncate, just as in Thija (Land (24)) and other Cupressoïdeae, while the pollen-tube has not penetrated more than half-way from the apex of the nucellus to the apex of the prothallus.

A number of preparations have been obtained showing the formation of alveoli in various stages and the subsequent formation of closed cells. The first alveoli are seen growing in from the sides of the prothallus, while scarcely any trace of them can be seen growing down from the truncate apex (Pl. XLVI, Fig. 6I). From a comparison with later stages it seems fairly certain that the alveoli, usually about nine or ten in number, destined to form 
archegonium initials, lag very slightly behind the others. The result of this is that the central apical alveoli, instead of growing in simultaneously with those immediately surrounding them, grow down on to their walls. In this way the apical archegonium initials are from the first distinct from all the other alveoli (Figs. 39 and 62). Land's (24) figure of archegonium initials in Thuja rather suggests that a similar lagging of the alveoli which will form archegonium initials may take place in that genus (and, doubtless, in other Cupressoïdeae). In contrast with the Callitroïdeae, the alveoli remain unsegmented until they almost meet in the central axis of the prothallus, and then (except the archegonium initials) divide up more or less evenly into several cells; in the Callitroïdeae a small tabular cell is cut off from the base of each primary cell before it extends more than about halfway inwards. In Libocedrus, Lawson (27) describes the alveoli as forming several transverse divisions while they grow inwards, but this does not occur in Tetraclinis; it is likely that there may be differences in this respect between closely related plants, as shown by Arnoldi ( 1 and 2 ) in the two species of Sequoia.

The first division of the archegonium initials occurs soon after the beginning of segmentation of the primary prothallus cells, and results in the formation of the central cell of the archegonium and a primary neckcell (Fig. 40). The neck-cell soon divides again in a vertical plane, and each daughter-cell again in the other vertical plane, forming a single tier of four cells in the neck. At the same time the central cell rapidly enlarges, while the surrounding prothallus cells go on growing and dividing to keep pace with it. The archegonia (Figs. 4I, 42, and 63-5) form an apical complex exactly similar to that met with in other Cupressoïdeae ${ }^{1}$ the cells immediately surrounding the complex form a fairly well-defined jacket layer, as in Thuja, Funiperus, and other genera. The nucleus of the central cell at first lies in a small mass of cytoplasm just below the neck. The cytoplasm also extends as a thin parietal layer round the inside of the wall, but the whole of the central part of the archegonium is occupied by one large vacuole (Fig. 63). As the archegonium matures, a small mass of protoplasm is also seen at the base of the archegonium, and this gradually enlarges so that the vacuole is completely obliterated before the archegonium is ready for fertilization (Figs. 4I, 64).

The number of neck-cells also increases during the development of the archegonium, there being finally two tiers of neck-cells, sometimes with more than four cells in a tier. The arrangement varies somewhat, but the commonest type of neck appears to consist of two tiers of four cells each. (See Figs. 4I, 4.2, 45, and 46.)

1 Cunninghamia (Miyake (32)) has a somewhat different arrangement of the archegonia, with a patch of sterile cells in the centre of the complex. 
Shortly before the ventral canal nucleus is cut off, the bodies appear which are referred to by Nichols (36) in Funiperus as asteroids, and by Norén (37) in the same genus as 'Strahlungszentren'. These structures bear some resemblance to blepharoplasts, and it is not without interest to find such bodies occurring just prior to the division which gives rise to the egg in Conifers, although no trace of a blepharoplast has ever been demonstrated in the division to form male cells in any Conifer. The asteroids seem of general occurrence amongst Cupressoïdeae, having been reported by Land (24) in Thija and by Coker (9) in Taxodium, as well as in Funiperus, as mentioned above. They were seen by Norén (37) in Tetraclinis also. In archegonia which are not fertilized the asteroids become both more conspicuous and more numerous, but they have not been noticed after fertilization has been effected. They may be seen in some of the archegonia of Fig. 65.

The last change in the archegonium before fertilization is the cutting off of a ventral canal nucleus (Figs. 43 and 44). The fate of this nucleus seems to vary; in some cases no trace of it can be found at a somewhat later stage, while in others it may easily be seen associated with proembryos of various ages.

The number of archegonia in a prothallus is usually nine or ten in my material (Fig. 65), but higher numbers are sometimes met with; Strasburger (52) gives the number as fifteen or more, so that the number probably varies somewhat widely. Since my material was all collected from a single tree, it is not improbable that the number of archegonia in a prothallus may have been below the average.

One of the most interesting features of the female gametophyte is the somewhat rare occurrence of lateral groups of archegonia. These are mentioned by Juel (21) and Norén (37) as an occasional abnormality in the genus. In a literal sense it is certain that such lateral groups are abnormal for this plant, but in the sense in which 'abnormal' is generally used, as indicating something of the nature of a freak, it does not seem clear that a phenomenon which is thus known to occur with some regularity in a proportion (though only a small proportion) of cases should be looked upon as entirely 'abnormal' - at least, it must be regarded as a factor which cannot be overlooked in considering the phylogenetic relationships of the plant in which it occurs. Of those prothalli sectioned by me, about I 30 were of an age sufficient to show the archegonia; of these, three (from separate cones collected on three different dates) had lateral archegonia. Of these three, one (Text-fig. 2) shows a perfectly normal group of archegonia at the apex, and, in addition, a similar group of ten archegonia placed laterally a short distance below the apex. The second (Text-fig. 3) has no archegonia at, or anywhere near, the apex. There are two lateral groups, one about half-way down the prothallus, consisting of six archegonia, and another about two- 
thirds of the way down, which was unfortunately cut through when the prothallus was fixed, so that the number of archegonia cannot be counted; two, at least, can be clearly seen, and in the sketch the group has been hypothetically restored. The third preparation (Text-fig. 4) resembles the
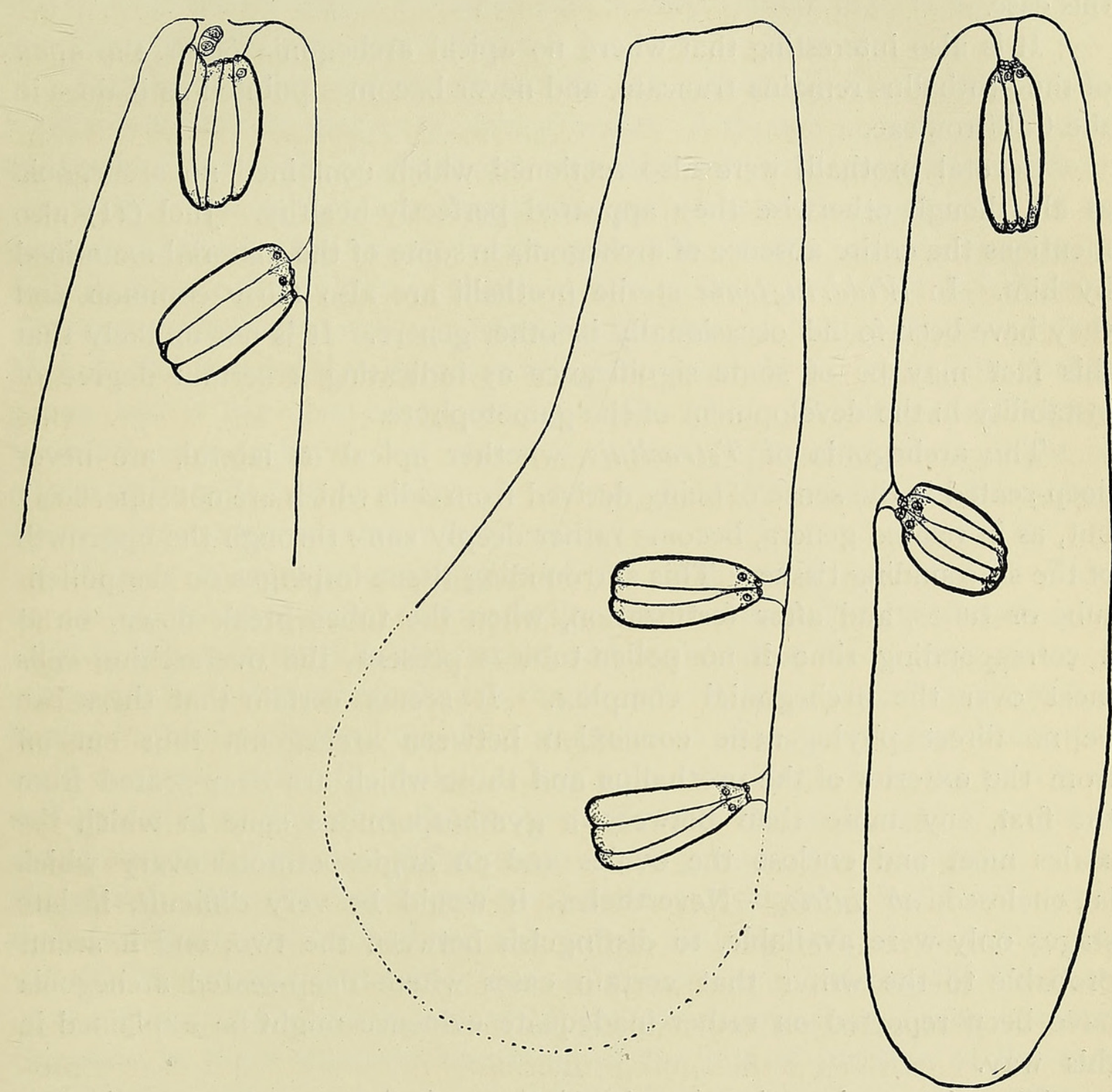

TEXT-FIG. 2.-Median longitudinal section of apical part of a prothallus of Tetraclinis, containing both apical and lateral groups of archegonia. $\times 35$. Sept. 2.
TEXT-FIGS. 3 AND 4.-Median longitudinal sections of two prothalli of Tetraclinis, containing lateral groups of archegonia. Both $\times 35$. Fig. 3, Sept. 23. Fig. 4, Oct. 3 .

first in having one apical and one lateral group of archegonia, but in this case the lateral group lies about half-way down the prothallus.

It is noteworthy that each prothallus which shows lateral archegonia is very healthy and well developed. In each case pollen-tubes are developing quite normally through the nucellus, and the archegonia themselves appear normal in other respects, and healthy. There is not the slightest indication 
in any of the three that failure to develop in the usual way is due to injury. As mentioned above, the suggestion has been made that cultural conditions are responsible for this peculiarity, but the tree from which my collections were made was growing in the open in a climate not very dissimilar to that of its native land, and such a suggestion does not seem adequate in this case.

It is also interesting that where no apical archegonia occur, the apex of the prothallus remains truncate, and never becomes pointed as it does in the Callitroïdeae.

Several prothalli were also sectioned which contained no archegonia at all, though otherwise they appeared perfectly healthy. Juel (21) also mentions the entire absence of archegonia in some of the material examined by him. In Widdringtonia sterile prothalli are also fairly common, and they have been found occasionally in other genera. It is not unlikely that this fact may be of some significance as indicating a certain degree of instability in the development of the gametophyte.

The archegonia of Tetraclinis, whether apical or lateral, are never deep-seated in the sense of being derived from cells which are not superficial, but, as in related genera, become rather deeply sunk through the upgrowth of the surrounding tissue. This surrounding tissue impinges on the pollentube or tubes, and after fertilization, when the tubes break down, or at a corresponding time if no pollen-tube is present, the overarching cells meet over the archegonial complex. It seems certain that there can be no direct phylogenetic connexion between archegonia thus cut off from the exterior of the prothallus and those which are deep-seated from the first, any more than between a gymnospermous cone in which the scales meet and enclose the ovules and an angiospermous ovary which is enclosed $a b$ initio. Nevertheless it would be very difficult, if late stages only were available, to distinguish between the two, and it seems probable to the writer that certain cases where deep-seated archegonia have been reported on rather inadequate evidence might be explained in this way.

The dates given in the description of figures, corresponding to the dates of collection of different stages, do not suffice to fix the time which elapses between pollination and fertilization. Pollination occurred in the oldest ovules seen about April 20, but the majority were certainly pollinated later, probably up to June I or a little after. At each collection the largest and oldest cones available were gathered, so that those ovules in which post-fertilization stages were first found (on September 2) were not pollinated at the same time as those of the earlier collections, but probably about a month later. Consequently the actual time which elapses between pollination and fertilization is from 3 to $3 \frac{1}{2}$ months. 


\section{Fertilization And Development of the Proembryo.}

As in other Cupressoïdeae, it is customary for both the male cells to be functional, passing into and fertilizing two adjacent archegonia. One case has been seen, however, where all four nuclei were discharged from the pollen-tube into a single archegonium ; a very similar case is figured by Knischewsky (23, Fig. 45) in Thuja.

Post-fertilization stages are readily recognized by the starch sheath which invariably surrounds the fusing nuclei. Although no very conclusive evidence of the origin of the sheath was obtained in the present case, there can be little doubt that it is simply the cytoplasm of the male cell. It is curious, however, that starch is not noticeable in the mature, or nearly mature, male cell, while it is always a conspicuous feature of the sheath. The same peculiarity was remarked by Strasburger (53) in Funiperns, but Nichols (36) succeeded in demonstrating the starch in the male cells of this genus, and it has also been seen by Coker (9) in Taxodium; it seems, therefore, very probable that starch is commonly present in the cytoplasm of the male cells, but in rather an obscure form in some cases, becoming much more conspicuous after fertilization.

Fig. 47 shows the conjugation of the male and female nuclei. This case is typical of four out of five similar stages seen. The male nucleus is considerably smaller than the female, and in the latter the nuclear contents are somewhat more scanty than in the former. A large reticulate nucleolus is seen in the female nucleus. Fig. 48 shows an exceptional case where the male nucleus is below the female. It is quite clear, both from the structure and the relative size, that the lower nucleus is the male, and it may be mentioned that the actual difference in size is greater than is apparent from the section, since the female nucleus extends considerably further than the male in the sections both above and below that figured. I should doubt whether the volume of the male nucleus is ever more than one-third of that of the female. Fig. 49 shows one of two cases seen where fusion is quite complete, no trace whatever remaining of the line of junction of the two nuclei. The structure, however, is simply that of a resting nucleus, so that here fusion is entirely complete before any preparations are made for the first sporophyte division. In Pinus (Blackman (4), Chamberlain (6), Ferguson (17)) preparation is made for this division by both nuclei before the membrane between them breaks down, and no mingling of the nuclear contents takes place until after chromosomes are organized, and although no other genus has been investigated so completely, it appears probable that the same is true for other Pinaceae. The records for other families are so scanty that it is not possible to generalize; in Funiperus, however, both Norén (37) and Nichols (36) record complete fusion of the two nuclei in the resting stage. 
In Pinus the two groups of chromosomes remain distinct during the formation of the spindle, a phenomenon also occurring in Larix (Woycicki, as quoted by Coulter and Chamberlain (12)), Tsuga (Murrill (35)), Funiperus (Noren (37), Nichols (36)), and Cunninghamia (Miyake (32)), and doubtless true for most, if not all, other Conifers. In Tetraclinis two distinct groups of chromosomes are formed, which can be made out quite plainly at the time when spindle fibres begin to appear.

Figs. $5^{\circ}$ and $5^{\mathrm{I}}$ are drawn from two adjacent sections of the same series. The sections did not pass medianly through both groups of chromosomes in the same section, but Fig. 50 is the one which includes the point of junction of the two groups. Fig. 5I has passed through practically the centre of the male group, while only outlying parts of three or four female chromosomes are shown. The next section on the other side shows female chromosomes almost solely, a few fragments only of the male being visible above. In all three sections, also, the spindles are distinct as well as the chromosomes.

Funiperus is the only other genus of plants where such a segregation of chromosomes has been clearly proved to follow complete fusion of the male and female nuclei-complete, that is, as far as revealed by the highest powers of the microscope-and these two cases, which are probably duplicated in other Cupressoïdeae, appear to the writer to constitute the most important cytological evidence we at present possess in plants in regard to the continued individuality of male and female chromosomes. To these should be added Miss Ferguson's (17) demonstration of segregation in Pinus at the second division in the proembryo, a record which has not been repeated for any other genus of plants, but which is duplicated in the cleavage of the fertilized egg of Cyclops (Ruickert (43)) amongst animals.

A rough count of the chromosomes in these sections indicated a considerably higher number than was expected, but this was proved to be due to the length and very irregular shape of the chromosomes, so that not only does one chromosome certainly appear in more than one section in some cases, but almost certainly two separate parts of the same chromosome may appear in the same section. As it is quite impossible to trace out the whole length of each individual chromosome, it was assumed that the longest whole thread of chromatin which could be demonstrated was a whole chromosome, an assumption which may be considered reasonably probable; this was carefully drawn and measured, making some allowance for the change of focus required to bring successive parts of the thread into view ; each piece of thread appearing in the same half (female) of the three sections was drawn and measured in a similar manner, and the total length of thread obtained in this way was divided by the length of one chromosome. The probable error in such an estimate might be taken at about Io per cent., and the fact that the actual figure obtained was almost exactly 12 makes 
it practically certain that no splitting of the chromosomes had occurred at this time.

In the next figure (Fig. $5^{2}$ ) the chromosomes have become arranged at the equator of a multipolar spindle, but apparently no splitting has as yet taken place. Fig. 53 shows the daughter chromosomes approaching the poles of the spindle.

It may be noted that each of these three stages (Figs. 50-3) is found near the centre of the archegonium, a position which appears to be normal for Cupressoïdeae, having been observed by Lawson (26) in Cryptomeria and by Miyake (32) in Cunninghamia. In Thija, according to Land (24), the division takes place below the centre, but not quite at the base. In Taxodium, however, Coker (9) reports that the fusion nucleus passes to the base of the egg before dividing.

Figs. 54 and 66, which represent the next stage seen in Tetraclinis, show the two daughter nuclei one above the other at the base of the egg, evidently shortly after division is completed. Whether the daughter nuclei pass down before or after the completion of the first mitosis cannot be stated. The next division results in the formation of a tetrad of free nuclei (Figs. 55, 56, and 67), the tetrad being oriented, in different cases, in every conceivable manner; it seems likely that the variation met with at this time may explain the still greater variation met with in the proembryo after walls have appeared.

Figs. 56, 66, and 67 show how small a proportion of the egg is occupied by the young proembryo, and Fig. 56 also shows the ventral canal nucleus. It may be mentioned that in Tetraclinis the ventral canal nucleus has never been seen to divide after fertilization has occurred, contrary to the case of Thuja (Land (24)) and Funiperus (Nichols (36)), where division quite often occurs. The next stage seen shows a proembryo, in which walls have been formed, containing eight cells; it seems probable that the walls appear, as is usual, in the transition from the 4-nucleate to the 8-nucleate stage, though a different method of wall formation has been described in Thija (Land (24)). No detailed drawings have been made of these later stages of the proembryo. That no simultaneous divisions occur after wall formation may be inferred from the fact that counts of the cells (including the upper tier of free nuclei, where such was present, which was usually not the case) in serial sections of fourteen walled proembryos (before they extend into the prothallus below the base of the archegonium) gave the following numbers of cells: 8, 9 (two examples), IO, II, I2 (two examples), 13, I5, I6 (two examples), I7, I8 (two examples). Five of the least irregular of these have been used as the basis of Diagrams I to 5 in Textfig. 5. These, however, are in each case slightly more regular than the originals, though the general arrangement of tiers appears to be essentially accurate. The number of cells (or nuclei) in each tier is indicated on the 
left of each diagram, and the total number below these. The ventral nucleus is also indicated in Diagram 5. It may be noted that it is usual, but not invariable, for the lowest tier to consist of only a single cell.

Only scattered stages were examined beyond this, the chief point of interest being that two or three tiers of cells contribute to the suspensor. This has been found to be the case also in Thija (Land (24)) and Torreya (Coulter and Land (11)), and is said (Coulter and Chamberlain (12)) to be usual amongst ' Taxaceae' (Taxads and Podocarps).

As recorded by Hansen (19), the number of cotyledons in the embryo ranges from three to six. Text-fig. 6 shows a transverse section of an embryo with three cotyledons, while Text-fig. 7 is from a drawing of an embryo with five. The only other embryo dissected had four cotyledons. It may be worth

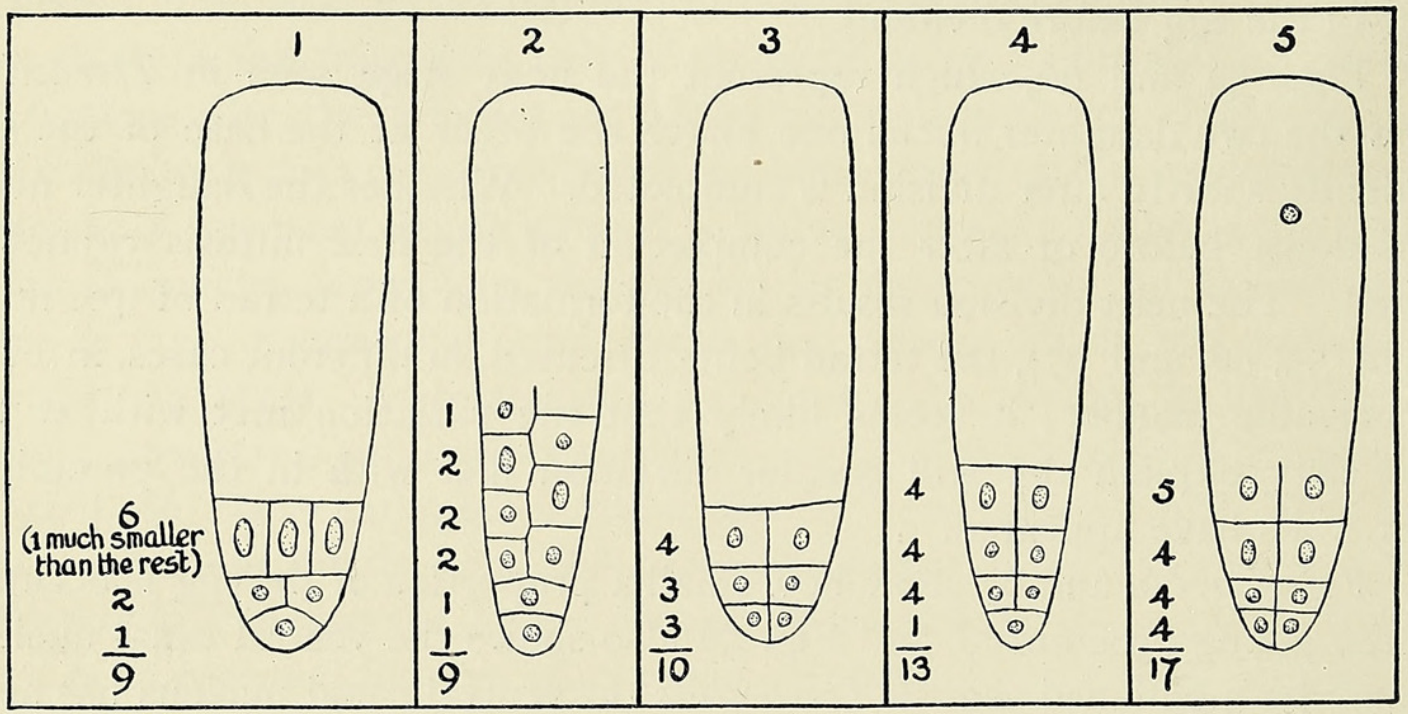

TEXT-FIG. 5.-Series of diagrams to illustrate some of the arrangements of cells met with in walled proembryos of Tetraclinis.

noting that two to five cotyledons are found in Funiperus (Coulter and Chamberlain (12)), while among Callitroïdeae, Widdringtonia occasionally has three, but usually agrees with the other two genera, which invariably possess only two. ${ }^{1}$

There is one peculiarity in the mature seed which has apparently not been recorded before, namely, that the testa is soft, thin, and membranous. There could be no doubt that the seeds examined were mature. They were collected at the same time as the youngest cones of the succeeding crop, and the cones in which they were found were wide open and had already shed most of their seeds (all, except in a few cases). The embryos of Text-figs. 6 and 7 were dissected out from two of these seeds, and the remainder (about three or four) were planted but did not germinate.

Certain other points, best seen in, or confined to, prothalli containing proembryos may now be discussed.

1 Lubbock (30) states, incorrectly, that Actinostrobus pyramidalis has three cotyledons. No single case has been seen by me, out of a large number of seedlings (certainly more than one hundred), where more than two cotyledons were present. 
Appearances, difficult to interpret, seen in the megaspore membrane at this time, led to a very careful examination of that structure. According to Thomson (54) this membrane consists, in the Cupressoiddeae, of an endospore and exospore, represented in his figures as of approximately equal thickness. The endospore is more or less homogeneous, while the exospore consists of numerous slender radiating rods. He also mentions that material derived from nucellar tissue may increase the apparent thickness of the exospore. As to the last point, the deeply staining deposit on the outside of the exospore does, in many cases, obscure its structure, but here and there parts may be found which are free from it. In order to see the structure clearly it is also necessary not only to select a part which shows no trace of 'dragging' (as Thomson mentions), but also one which is cut almost exactly perpendicular to its own plane, so that a slight change of focus produces no

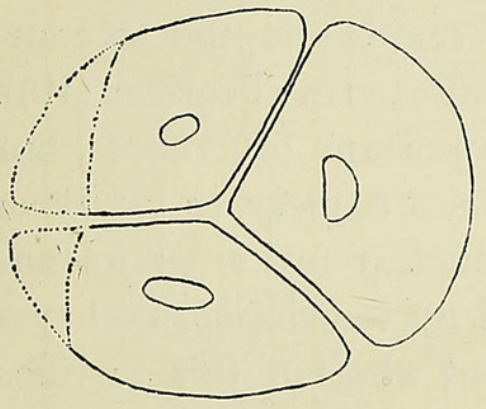

Text-Fig. 6. - Transverse section through the cotyledons of a tri-cotyledonous embryo. $\times 35$.

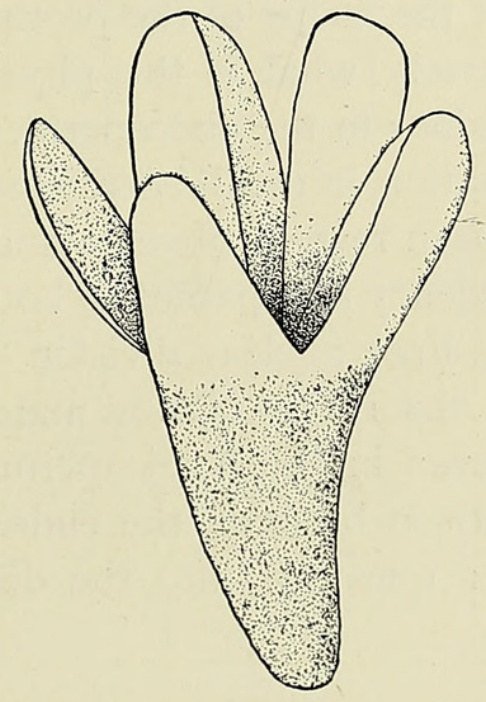

TEXT-FIG. 7.-Sketch of an embryo with five cotyledons. $\times 16$.

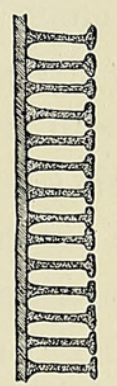

TEXT-FIG. 8.-A very small part of the megaspore membrane of Tetraclinis in longitudinal section. The outer side to the right. $\times$ circa 3000 .

lateral displacement of the image. Having satisfied these conditions, it is possible to distinguish in Tetraclinis a very thin homogeneous endospore, which I should estimate at only one-sixth of the total thickness of the membrane, and an exospore which consists of rods thickened in a dumbbell-like manner at the apex, so that with a lens which does not resolve in an entirely satisfactory manner, the outer layer of the exospore appears continuous, while the inner and thicker layer appears to contain numerous radiating vacuoles. Text-fig. 8 represents a sketch of the structure as seen with a high magnification. It will be seen to be similar to that figured by Chamberlain ( 7 and 8) for Dioon and Ceratozamia, except that the terminal swelling of the rods is more abrupt. It would be interesting to know whether a re-examination of other Gymnosperms would show that a similar structure is more widely prevalent. It may be mentioned that a figure of the megaspore membrane of Funiperus given by Norén (37) shows a structure quite similar to that seen in Tetraclinis when the resolving power of the lens 
used is not entirely satisfactory. It differs considerably from Thomson's (54) figures of the membrane in Cupressoïdeae. The actual thickness of the membrane in Tetraclinis is just under $2 \mu$.

In a recent paper the writer (47) has discussed the extent to which multinucleate prothallus cells are found in the Conifers, in connexion with their regular occurrence in the Callitroïdeae. In Tetraclinis such cells occur fairly freely, but frequently show a subsequent fusion of the nuclei within the cell. Such a stage was carefully looked for in the genera of Callitroïdeae, but was never discovered. Figs. 57 and $5^{8}$ show various unfused, fusing, and fused nuclei, all drawn from different parts of the same section. There is no difficulty in finding such stages, and it may be taken as certain that such a fusion of nuclei would have been readily found if it did occur in the Callitroïdeae. This observation explains Juel's (21) remarks as to the great variation in size of the nuclei of the prothallus cells in Tetraclinis. It is not easy to see precisely what is the physiological meaning of these nuclear divisions and fusions in the endosperm, but one is tempted to compare them with the situation in the Welwitschia endosperm (Pearson (40)). In detail such a comparison reveals obvious and important differences, but yet the same sort of tendency is apparent in both cases, namely, to establish the following sequence: Free nuclear division $\rightarrow$ nuclear fusion $\rightarrow$ formation of food material $\rightarrow$ absorption of food material by developing embryo. The same tendency is seen in the Angiosperms, but whether this justifies a morphological comparison between the endosperm in Gymnosperms and Angiosperms is another question, into the discussion of which it is not proposed to enter.

\section{PHyLOGENy.}

Tetraclinis is evidently quite a typical genus of the Cupressoïdeae, but nevertheless, there are several points which agree in indicating a high degree of probability that it must have been through some plant closely resembling Tetraclinis that the southern sub-family Callitroïdeae were derived from the essentially northern sub-family Cupressoïdeae. One of the chief regions of distribution of the Cupressoindeae may be said to be Europe and Middle Asia; Tetraclinis occurs in Northern Africa (Algeria and Morocco, chiefly), while one species of Funiperus (F. thurifera) is also found in Algeria, and another species is stated by Drude (13) and Engler (15) to occur in tropical Africa. Funiperus appears to be more closely related to Tetraclinis than any other genus of Cupressoïdeae, and it is therefore not surprising to find species of the former geographically associated with the monotypic Tetraclinis. The tropical species of Funiperus (F.procera) and Widdringtonia Whytei are both found in the mountains of Central Africa at altitudes of from 5,000 to 10,000 feet, while, passing south, we have successively Widdringtonia Mahoni, W. Schwarzii, W. juniperoides, and 
$W$. cupressoides. Among various morphological points indicating a close relationship between Funiperus and Tetraclinis are the delayed division of the microspore nucleus, the structure of the female cone and ovules, and some other resemblances noted in detail above. It is noteworthy also that occasional development of lateral archegonia, as described in Tetraclinis, has also been described and figured by Norén (37) in Funiperus, although of a somewhat different type to that met with in Tetraclinis.

The early development of the ovule of Tetraclinis is very similar to that of Widdringtonia (except for the absence of a depression at the apex

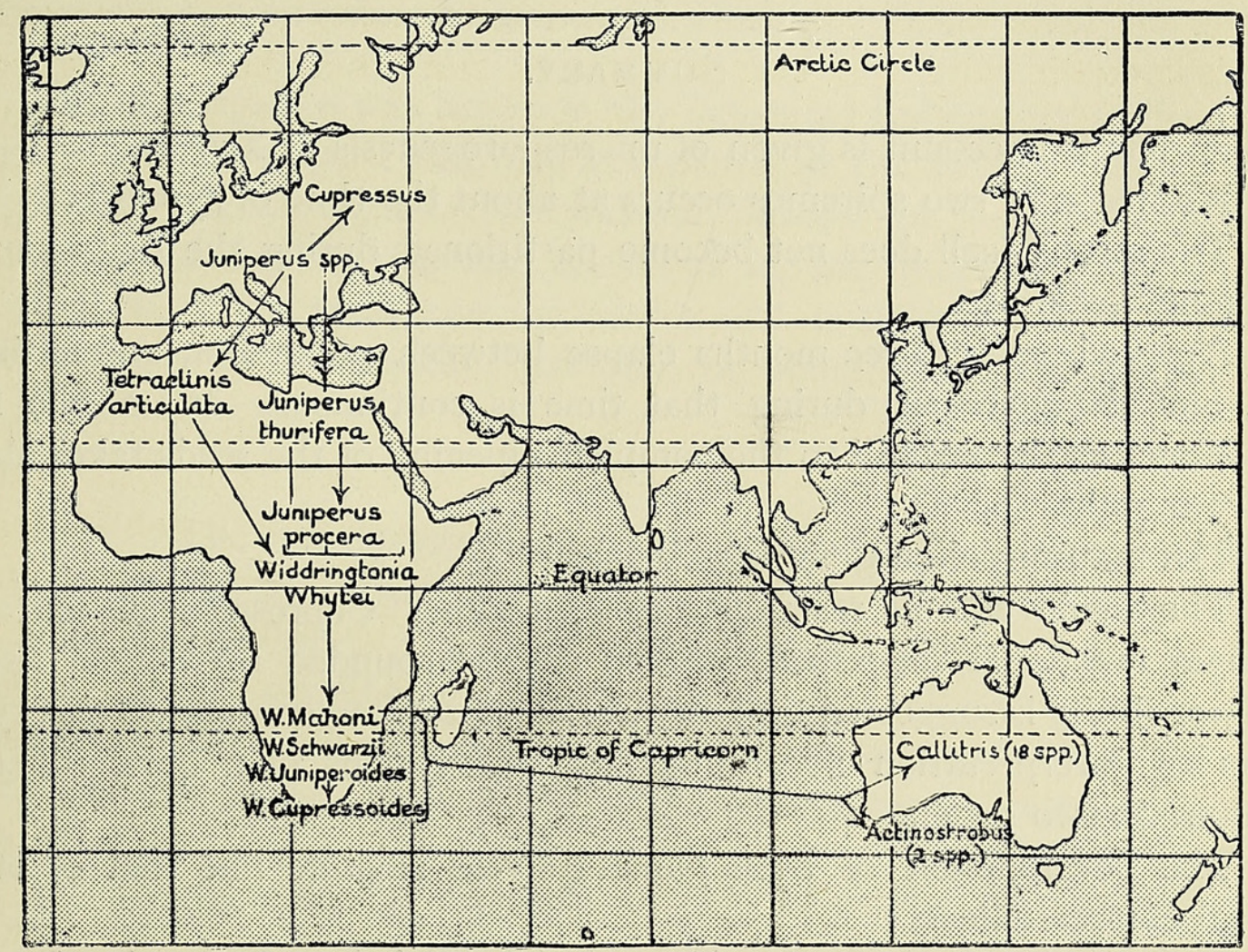

TEXT-FIG. 9.- Part of a map of the world, showing the distribution and suggested phylogeny of the Callitroïdeae and of certain Cupressoïdeae.

of the nucellus in the latter), while the development of lateral archegonia in the prothallus has become a fixed character in Widdringtonia, no apical archegonia having been ever observed. In Widdringtonia, however, the position and extent of the lateral groups is much more variable than in Callitris and Actinostrobus. It may also be noted that the development of the proembryo, as far as has been seen, while substantially similar in Widdringtonia, Callitris, and Actinostrobus, is less constant in Widdringtonia than in the other two genera, and differs somewhat less widely from the Cupressoïdeae type. The variability of the Tetraclinis proembryo has already been pointed out.

Points such as these suggest that the phylogeny of the three genera of the Callitroildeae, and of the two genera of Cupressoïdeae to which they are considered to be most nearly related, is somewhat as shown in Text-fig. 9. 
(Since it is considered that in the present case the phylogeny has followed more or less definite geographical lines, the phylogeny and the geographical distribution have been indicated together on a sketch-map.)

The geological and general biological evidence for the former existence of a great antarctic continent, providing a land connexion between Southern Africa and Southern Australia, is very strong; the view that the separation of Actinostrobus and Callitris from Widdringtonia took place during this period would be more or less in agreement with the conclusions reached on general grounds as to the antiquity and relationship of these genera.

\section{SUMMARY.}

A detailed account is given of microsporogenesis in Tetraclinis. No fusion of two spiremes occurs at about the time of synapsis.

The mother-cell does not become partitioned during the development of the microspores.

Approximately three months elapse between pollination and fertilization, and development during that time is continuous. From the first appearance of the strobili to the complete ripening of the seeds takes about twelve months.

The mature pollen-grain is uninucleate.

The ovule closely resembles that of other Cupressoïdeae, and has a single functional megaspore mother-cell, surrounded by tapetal tissue. The possibility is suggested that all the Cupressoïdeae conform to this type, errors of interpretation accounting for descriptions of a quite different structure in two genera.

The development of both gametophytes is quite like that of other typical Cupressoïdeae.

The occasional occurrence of lateral archegonia is an interesting feature.

In fertilization the male nucleus is about one-quarter of the size of the female.

Complete fusion of the male and female nuclei occurs while both are in the resting stage.

In the prophases of the first sporophyte division a segregation of the chromosomes into two groups occurs (presumably male and female). This is regarded as important evidence of the continued individuality of male and female chromosomes.

Wall-formation in the proembryo apparently occurs in the transition from the four-nucleate to the eight-nucleate condition.

The mature proembryo is somewhat variable in the number and arrangement of the cells, but is always confined to the lower part of the fertilized archegonium.

More than one tier of cells takes part in the formation of the suspensor. 
Three, four, and five cotyledons were found respectively in the three mature embryos examined.

The $x$ and $2 x$ numbers of chromosomes are 12 and 24 respectively.

Arguments are brought forward to show that the Callitroïdeae were derived from the Cupressoideae through some plant closely resembling Tetraclinis. The general trend of evolution is considered to have followed a line from Northern to Southern Africa, and thence, by means of a former antarctic land connexion, to Australia. Thus Widdringtonia is the most primitive of the Callitroïdeae, and differs least from the Cupressoïdeae, while Callitris and Actinostrobus are more specialized.

This investigation was begun in the Botanical Laboratory of the South African College, Cape Town, and completed at the Botany School, Cambridge. My thanks are due to Professor Seward for placing a room and research facilities at my disposal, as well as for the interest he has taken in the progress of the work, and for advice and criticism on certain points. I am also glad to acknowledge criticism on some cytological points from Mr. R. P. Gregory.

May, I9I3.

NOTE.-The nomenclature adopted for the families and sub-families has been altered somewhat from that used in the writer's previous papers on Conifer morphology. The classification adopted is discussed in a recent paper on Conifer classification (Saxton (48)). The alterations in nomenclature have been made in order to conform to the international rules. My thanks are due to Dr. C. E. Moss for assistance in the interpretation of these rules.

\section{LITERATURE CITED.}

1. ARnoldi, W.: Beiträge zur Morphologie einiger Gymnospermen. I: Die Entwicklung des Endosperms bei Sequoia sempervirens. Bull. Soc. Imp. Moscou, vol. xiii (N. S.), I 899 (1900), pp. 329-4I, Taf. VII, VIII.

2. der Embryogenie in der Familie der Sequoiaceen. Bull. Soc. Imp. Moscou, vol. xiv (N. S.), I900, pp. 449-76, Taf. VII, VIII.

3. Baker, R. T., and Smith, H. G. : A Research on the Pines of Australia. Sydney, Igro.

Ball, J. (with Hooker, J. D.). See Hooker and Ball.

4. Blackman, V. H. : On the Cytological Features of Fertilization and related Phenomena in Pinus silvestris, L. Phil. Trans. Roy. Soc., London, B., vol. cxc, I898, pp. 395-426, Plates XII-XIV.

5. Burlingame, L. L.: The Morphology or Araucaria brasiliensis. I: The Staminate Cone and Male Gametophyte. Bot. Gazette, vol. 1v, I9I3, pp. 97-I I4, Plates IV, V.

6. Chamberlain, C. J. : Oogenesis in Pinus Laricio. Bot. Gazette, vol. xxvii, I899, pp. 268-80, Plates IV-VI. 
7. Chamberlain, C. J. : The Ovule and Female Gametophyte of Dioon. Bot. Gazette, vol. xlii, I906, pp. 321-58, Plates XIII-XV.

8. : Morphology of Ceratozamia. Bot. Gazette, vol. viii, I9I2, pp. I-I9, Plate I. (with Coulter, J. M.). See Coulter and Chamberlain.

9. Coker, W. C. : On the Gametophytes and Embryo of Taxodium. Bot. Gazette, vol. xxxvi, I 903 , pp. I-27 and II $4-40$, Plates I-XI.

10. $:$ On the Spores of certain Coniferae. Bot. Gazette, vol. xxxviii, 1904, pp. 206-13.

11. Coulter, J. M., and Land, W. J. G.: Gametophytes and Embryo of Torreya taxifolia. Bot. Gazette, vol. xxxix, I905, pp. I6I-78, Plates A, I-III.

12.

13. Drude, O.: Handbuch der Pflanzengeographie. Stuttgart, I 890.

14. Eichler, A. W. : Coniferae. In Engler, A., and Prantl, K. : Die natïrlichen Pflanzenfamilien, Teil ii, Leipzig, $\mathbf{1} 889$.

15. Engler, A.: Die Pflanzenwelt Afrikas. Band ii, Leipzig, 1908.

16. Farmer, J. B., and Moore, J. E. S.: On the Meiotic Phase (reduction division) in Animals and Plants. Quart. Journ. Mic. Sci., vol. xlviii, 1905, 489-557, Plates XXXIV-XLI.

17. Ferguson, M. C.: Contributions to the Life-history of Pinus, with special reference to Sporogenesis, the Development of the Gametophytes, and Fertilization. Proc. Wash. Acad. Sci., vol. vi, I904, pp. I-IO2, Plates I-XXIV.

18. Goebel, K.: Outlines of Classification and Special Morphology. English translation, I887.

19. Hansen, C.: Pinetum Danicum. Journ. Roy. Hort. Soc., vol. xiv, 1892, pp. 257-480.

20. Hooker, J. D., and BALL, J. : Journal of a Tour in Morocco and the Great Atlas. London, 1878 .

21. Juel, H. O. : Ueber den Pollenschlauch von Cupressus. Flora, vol. xciii, 1904, pp. 56-62, Taf. III.

22. Juranyi, L. : Bau und Entwickelung des Pollens bei Ceratozamia longifolia, Miq. Jahrb. wiss. Bot., vol. viii, 1872 , pp. 382-400, Plates XXXI-XXXIV.

23. Knischewsky, O.: Beitrag zur Morphologie von Thuja occidentalis, L. Inaugural-Dissertation der Universität Zürich, 1905 .

24. Land, W. J. G.: A Morphological Study of Thuja. Bot. Gazette, vol. xxxiv, 1902, pp. 24959, Plates VI-VIII.

25. : Spermatogenesis and Oogenesis in Ephedra trifurca. Bot. Gazette, vol. xxxviii, 1904, pp. I-I8, Plates I-IV.

(with Coulter, G. M.). See Coulter and Land.

26. Lawson, A. A.: The Gametophyte, Fertilization, and Embryo of Cryptomeria japonica. Ann. Bot., vol. xviii, 1904, pp. 4I 7-44, Plates XXVII-XXX.

27. - The Gametophytes and Embryo of the Cupressineae, with special reference to Libocedrus decurrens. Ann. Bot., vol. xxi, 1907, pp. $28 \mathrm{I}$-30I, Plates XXIV-XXVI.

28. — : The Phase of the Nucleus known as Synapsis. Trans. Roy. Soc. Edinburgh, vol. xlvii, I9I I, pp. 59I-604, Plates I, II.

29. Lewis, I. M. : The Behaviour of the Chromosomes in Pinus and Thuja. Ann. Bot., vol. xxii, I908, pp. 529-56, Plates XXIX, XXX.

30. Lubbock, Sir J. : A Contribution to our Knowledge of Seedlings. Vol. ii, London, 1892.

31. Masters, M. T. : Notes on the Genera of Taxaceae and Coniferae. Journ. Linn. Soc., vol. xxx, I 893 , pp. I-42.

32. Mivake, K.: The Development of the Gametophytes and Embryogeny of Cunninghamia sinensis. Beih. Bot. Centrabl., vol. xxvii : i, I9I I, pp. I-25, Plates I-V.

Moore, J. E. S. (with Farmer, J. B.). See Farmer and Moore.

33. Mottier, D. M.: The Development of the Heterotypic Chromosomes in Pollen Mother-cells. Ann. Bot., vol. xxi, 1907, pp. 309-47, Plates XXVII, XXVIII.

34. - On the Prophases of the Heterotypic Mitoses in the Embryo-sac Mothercell of Lilium. Ann. Bot., vol. xxiii, I909, pp. 343-52, Plate XXIII.

35. Murrill, W. A.: The Development of the Archegonium and Fertilization in the Hemlock Spruce (Tsuga canadensis). Ann. Bot., vol. xiv, 1900, pp. 583-60\%, Plates XXXI, XXXII. 


\section{Life-history of Tetraclinis articulata.}

.36. Nichols, G. E.: A Morphological Study of Funiperis communis, var. depressa. Beih. Bot. Centralbl., vol. xxv : i, I 910, pp. 20I-4I, Plates VIII-XVII.

37. Norén, C. O.: Zur Entwicklungsgeschichte des Funiperus communis. Uppsala Universitets Årsskrift, 1907, pp. 64, Taf. IV.

38. Overton, J. B.: On the Organization of the Nuclei in the Pollen Mother-cells of certain Plants, with especial reference to the Permanence of the Chromosomes. Ann. Bot., vol. xxiii, 1909, pp. I9-6I, Plates I-III.

39. Pearson, H. H. W.: Some Observations on Welwitschia miralilis, Hooker, f. Phil. Trans. Roy. Soc. London, B., vol. cxcviii, I906, pp. 265-304, Plates XVIII-XXII.

40. : Further Observations on Welwitschia. Phil. Trans. Roy. Soc. London,

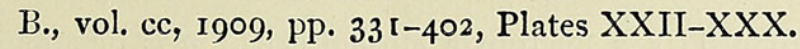

41. $:$ On the Microsporangium and Microspore of Gnetum, with some notes on the Structure of the Inflorescence. Ann. Bot., vol. xxvi, I9I 2, pp. 603-20, Plate IX.

42. Robertson, A.: Spore-formation in Torreya californica. New Phytologist, vol. iii, 1904, pp. I33-48, Plates III, IV.

43. RÜCKERT, J.: Über das Selbständigbleiben der väterlichen und mütterlichen Kernsubstanz während der ersten Entwicklung des befruchteten Cyclops-Eies. Arch. f. mikr. Anat., vol. xlv, 3, 1895, pp. 339-69, Plates XXI, XXII.

44. Saxton, W. T. : Preliminary Account of the Ovule, Gametophytes, and Embryo of Widdringtonia cupressoides. Bot. Gazette, vol. xlviii, 1909, pp. 16I-78, Plate XI.

45. - Contributions to the Life-history of Widdringtonia cupressoides. Bot. Gazette, vol. i, I9Io, pp. 3I-48, Plates I-III.

46. : Contributions to the Life-history of Callitris. Ann. Bot., vol. xxiv, 1910, pp. 557-69, Plates XLV, XLVI.

47. : Contributions to the Life-history of Actinostrobus pyramidalis, Miq. Ann. Bot., vol. xxvii, I9I3, pp. 32I-45, Plates XXV-XXVIII.

48. - The Classification of Conifers. New Phytologist, vol. xii, 1913, pp. 242-62.

$49 a$. Shaw, Thomas : Travel's, or Observations relating to several parts of Barbary and the Levant. ist ed. Oxford, I 738 .

49 b. — : The same. 2nd ed. Oxford, I757.

50. Sмiтh, F. G. : Morphology of the Trunk and Development of the Microsporangium of Cycads. Bot. Gazette, vol. xliii, 1907, pp. 187-204, Plate X.

Smith, H. G. (with Baker, R. T.). See Baker and Smith.

51. Sprecher, A. : Le Ginkgo biloba, L. Genève, 1907.

52. Strasburger, E. : Die Befruchtung bei den Coniferen. Taf. III, Jena, 1869.

53. Jena, $\mathbf{1} 884$.

54. Thomson, R. B.: The Megaspore Membrane of the Gymnosperms. Univ. Toronto Biol. Series, No. 4, p. 64, Plate V, $19{ }^{\circ}$.

55. Tison, A. : Remarques sur les gouttelettes collectrices des ovules des Conifères. Mém. Soc. Linn. Normandie, vol. xxiv, 19I I, pp. 5I-66, Plates III, IV.

56. Treub, M. : Recherches sur les Cycadées. I : Développement des sacs polliniques du Zamia uricata, Willd. Ann. Jard. Bot. Buitenzorg, vol. ii, 1885, pp. 33-4I, Plates I-IV. 


\title{
EXPLANATION OF FIGURES IN PLATES XLIV-XLVI.
}

\author{
Illustrating Professor Saxton's paper on Tetraclinis.
}

Note.-In the Plates all figures of longitudinal sections are oriented with the longer axis of the ovule vertical and the micropylar end upwards.

In all : $a=$ archegonium ; $b=$ body-cell $; c=$ micropyle closing cells ; $d=$ functional megaspore mother-cell; $e=$ egg nucleus; $f=$ sterile nuclei of the pollen-tube; $g=$ generative cell ; $h=$ tapetal cells; $k=$ tube nucleus; $m=$ male cells $; n=$ neck-cells $; p=$ functional megaspore; $q=$ non-functional megaspore; $s=$ starch sheath; $s p=$ sporogenous tissue; $t=$ pollen-tube ; $v=$ ventral canal nucleus $; \delta=$ male nucleus $; \uparrow=$ female nucleus.

\section{PLATE XLIV.}

Figs. I-26. Various stages in the development of the microspores from the microspore mothercell. All except Fig. 24 drawn from sections of fixed material, and $\times 1300$; Fig. 24 drawn from fresh material, and $\times 600$. All from material collected April 24-30, I9I2.

Fig. 27. Germinating pollen-grain, with generative cell and tube nucleus. $\times 600$. May 18 .

Fig. 28. Slightly older pollen-tube, with generative cell and tube nucleus; reconstructed from serial sections. $\times 600$. May II.

Fig. 29. Tip of older pollen-tube, with body-cell nucleus and two sterile nuclei; from two adjacent sections. $\times 600$. May $\mathbf{I} 8$.

Fig. 30. The tip of a pollen-tube shortly before the body-cell divides. $\times 600 . \quad$ June 28.

Fig. 3I. Median longitudinal section of young ovule, just before pollination. $\times 160$. April 24.

Fig. 32. The sporogenous tissue of the same ovule more highly magnified. $\quad \times 600$.

Fig. 33. The tip of the nucellus of a slightly older ovule, showing the characteristic breaking down of the apical cells. $\times 160$. April 27.

Fig. 34. Longitudinal section of the tip of an ovule just after pollination, to show the micropyle closing cells. $\times$ I60. May II.

Fig. 35. Transverse section of the same. $\times$ I60. April 27.

Fig. 36. Megaspore mother-cell and surrounding tissue. $\times 600$. May 18.

Fig. 37. Functional and non-functional megaspores, and tapetum. $\times 370$. Drawn from two adjacent sections. April 29.

Fig. 38. One of the thirty-two dividing nuclei in a young embryo-sac. $\times$ I, I00. May 18 .

\section{PLATE XLV.}

Fig. 39. Apex of a prothallus in longitudinal section, showing the archegonium initials. $\times 250$. August 12 .

Fig. 40. Very young archegonia, with primary neck-cells; drawn from several serial sections. $\times 370$. July 30 .

Fig. 4I. Longitudinal section of archegonial complex, and two pollen-tubes; reconstructed from several serial sections. $\times 160$. Sept. I I. Sept. 1 I.

Fig. 42. Part of a similar section to Fig. 4I ; drawn from several serial sections. $\times 370$.

Fig. 43. Part of archegonium, showing ventral canal nucleus recently cut off. $\times 53$. Sept. II.

Fig. 44. The same, a little later. $\times 530$. Sept. II.

Fig. 45. The neck of an archegonium from Fig. $4 \mathrm{I}$, in longitudinal section. $\times 530$.

Fig. 46. Transverse section through the neck of a mature archegonium. One nucleus was present in the next section, which has not been represented in the figure, $\times 530$. Sept. II.

Fig. 47. Fertilization. Male nucleus above. $\times 53$. Oct. 3 .

Fig. 48. The same. Male nucleus below. $\times 53$. Sept. 23.

Fig. 49. The fusion nucleus. $\times$ 530. Sept. 23. 
Fig. 50. Two groups of chromosomes and two spindles separating out in the prophase of the first sporophyte division. $\times$ 530. Sept. 2.

Fig. 51. The next section from the same series as Fig. $50 . \times 53^{\circ}$.

Fig. 52. Slightly later stage of the division of the fusion nucleus. $\times 530$. Oct. 3 .

Fig. 53. Later stage of division of the fusion nucleus. $\times 530$. Oct. 3 .

Fig. 54. Binucleate proembryo at the base of the archegonium. $\times 530$. Sept. 23.

Fig. 55. Four-nucleate proembryo at the base of the archegonium. $\times$ 530. Sept. 23.

Fig. 56. The same stage, but showing the whole archegonium and the ventral canal nucleus. $\times 225$. Sept. 23.

Fig. 57. Various nuclei, unfused, fusing, and fused, from prothallus cells of the same age as Figs. $54^{-6} . \times 530$.

Fig. $5^{8}$. Two fusing nuclei in a prothallus cell. $\times 530$.

PLATE XLVI. (Microphotographs).

(All $\times$ circa 100, except Fig. 60, which is $\times 25^{\circ}$.)

Fig. 59. Median longitudinal section of young ovule. (Cf. Fig. 3r.)

Fig. 6o. Functional megaspore, one of the two abortive spores, and surrounding tapetal tissue. (Cf. Fig. 37.)

Fig. 6r. Alveoli, showing the lagging in the development of those at the apex, as compared with the others. July 30 .

Fig. 62. Archegonium initials. (Cf. Fig. 39.)

Fig. 63. Young archegonia, showing very large vacuole filling the greater part of each. August I 2.

Fig. 64. Nearly mature archegonia, and end of pollen-tube showing two male cells. (Cf. Fig. 4I.)

Fig. 65. Transverse section through an archegonial complex, just below the necks. Note the 'asteroids'. Sept. I I.

Fig. 66. Binucleate proembryo. (Ct. Fig. 54.)

Fig. 67. Two four-nucleate proembryos in section. (Cf. Figs. 55, 56.) 
Annals of Botany
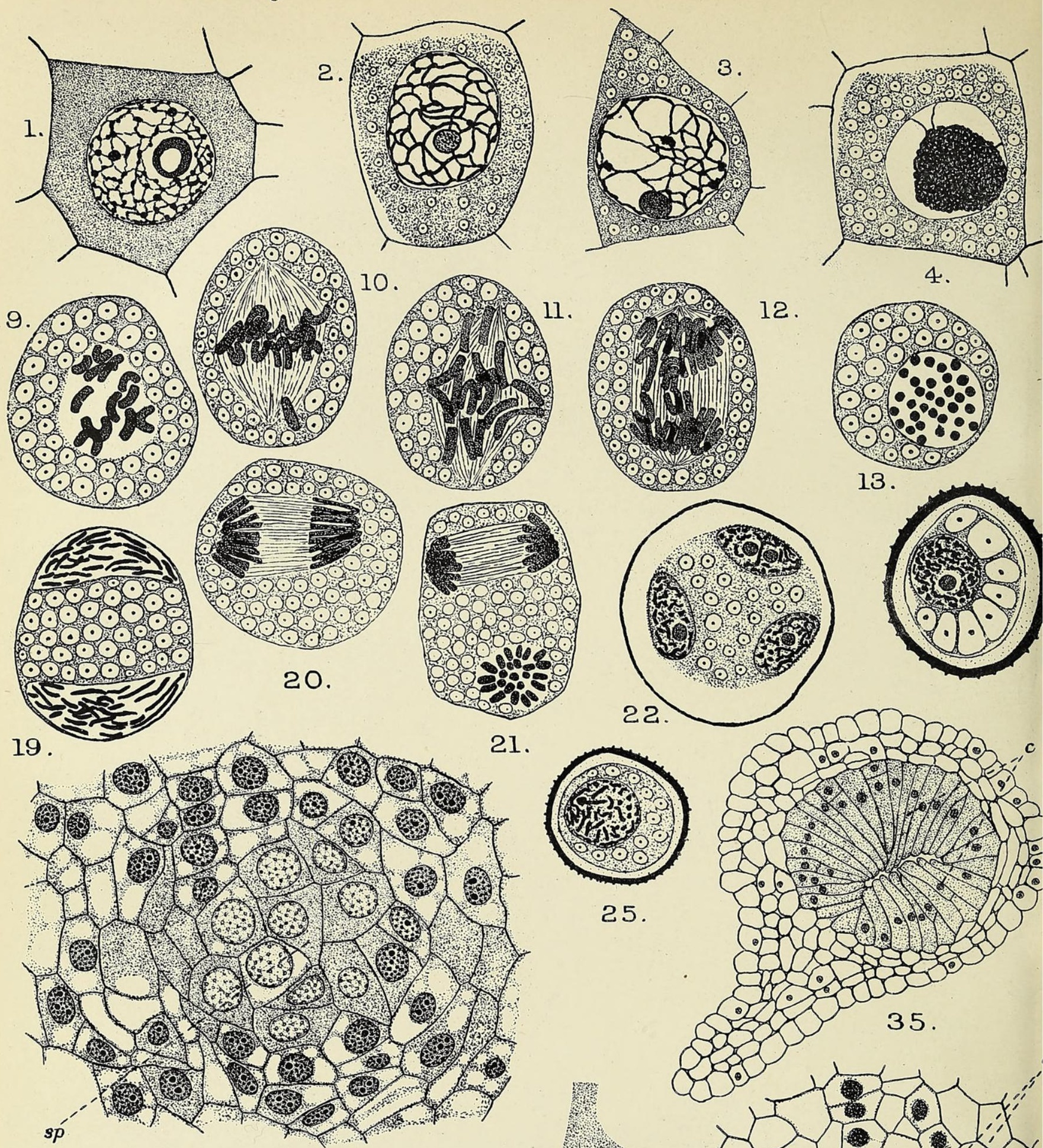

13.

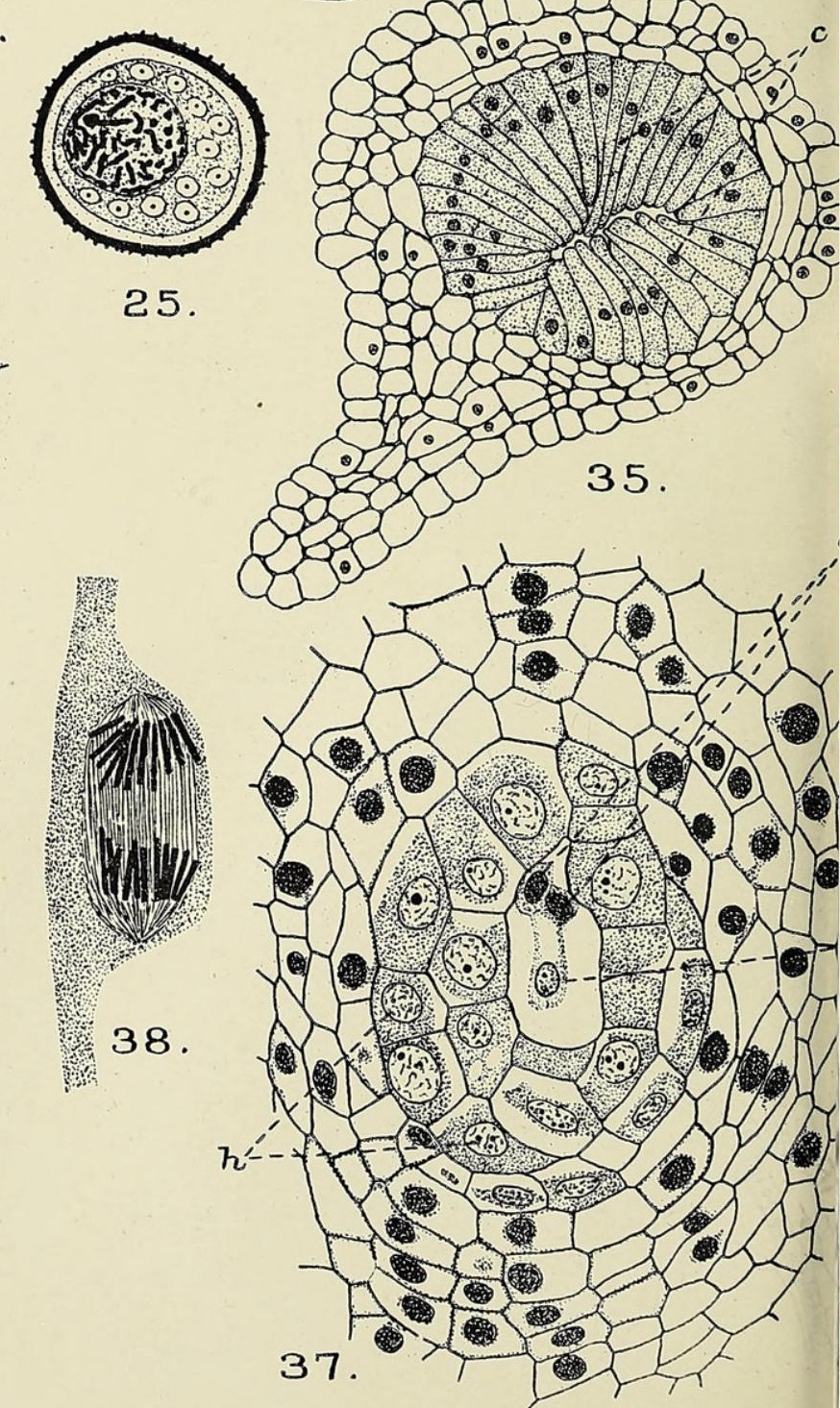



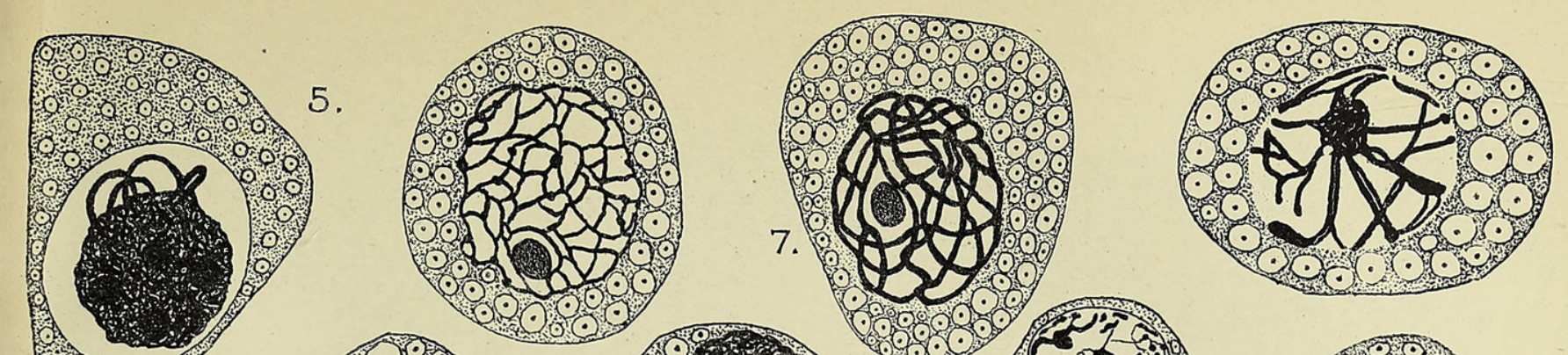

8.
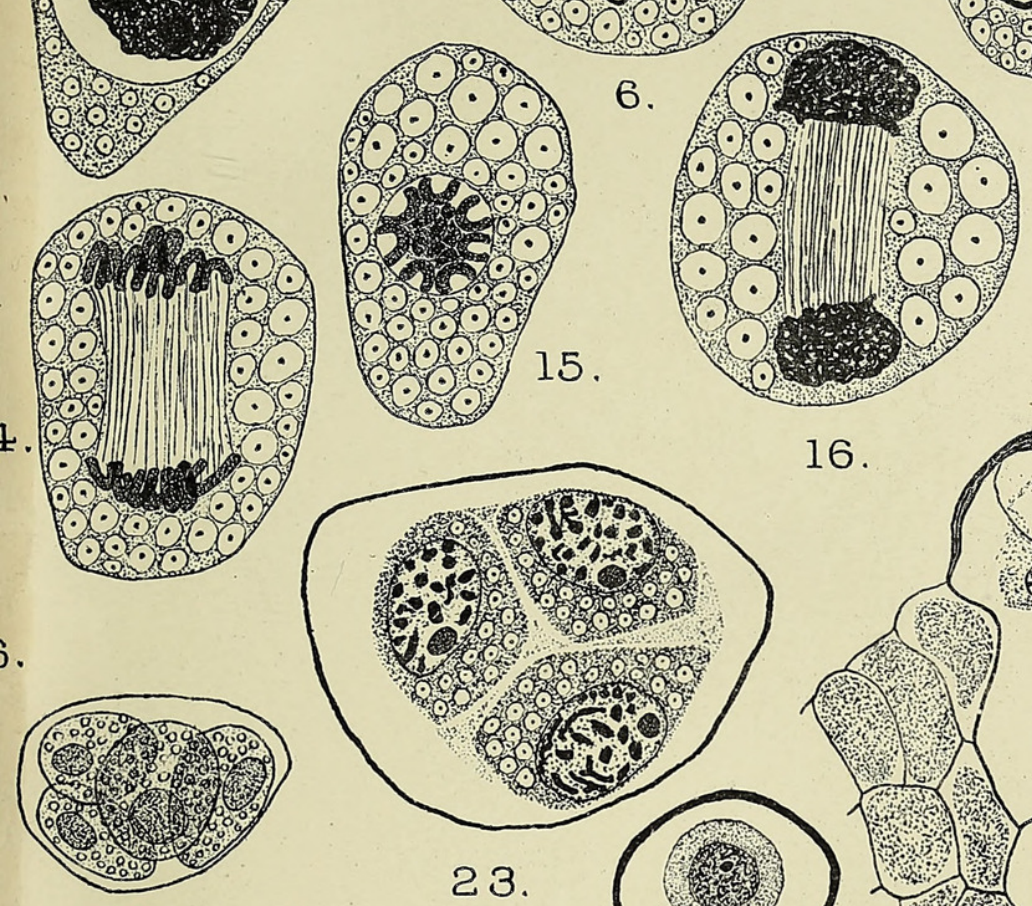

8
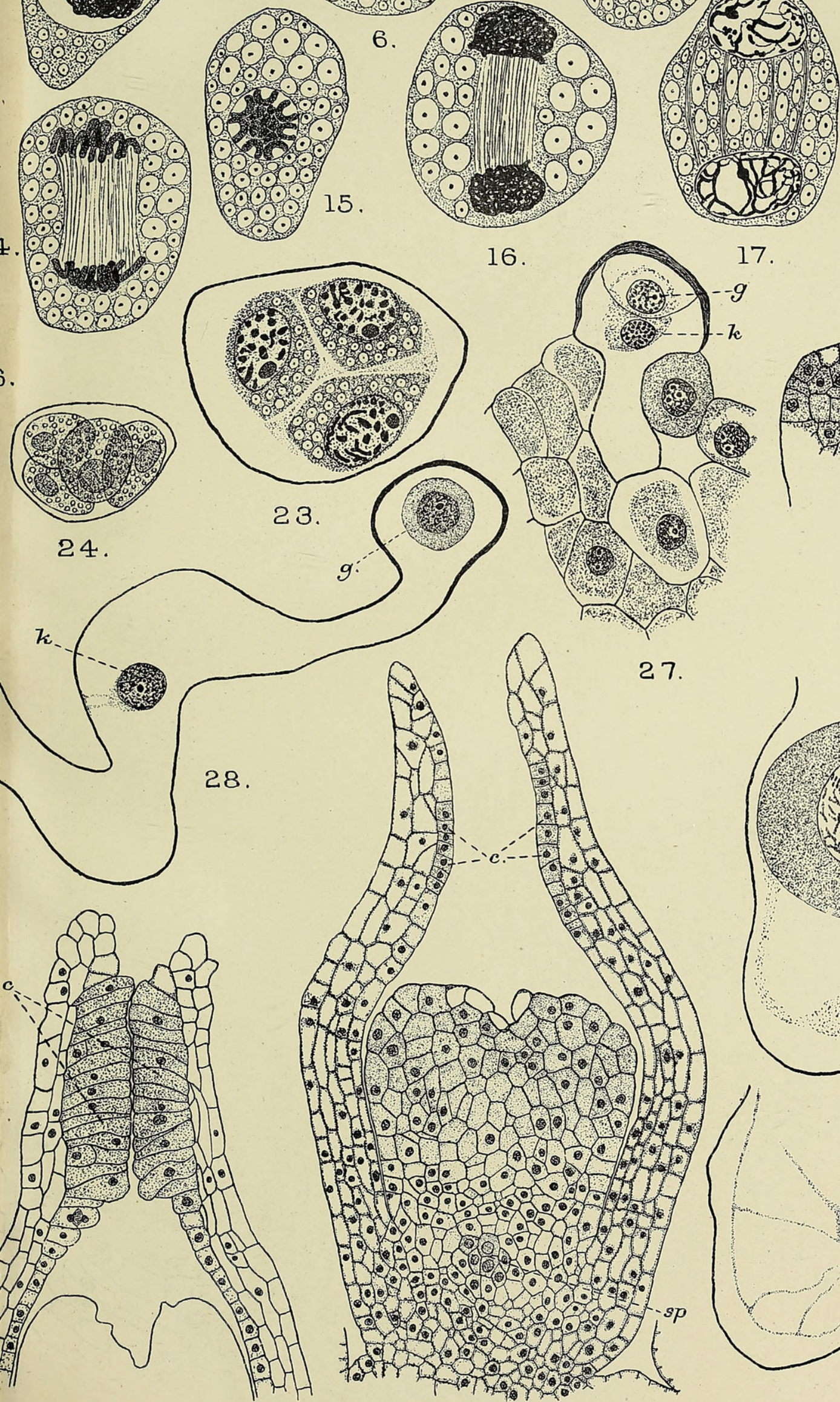

34.

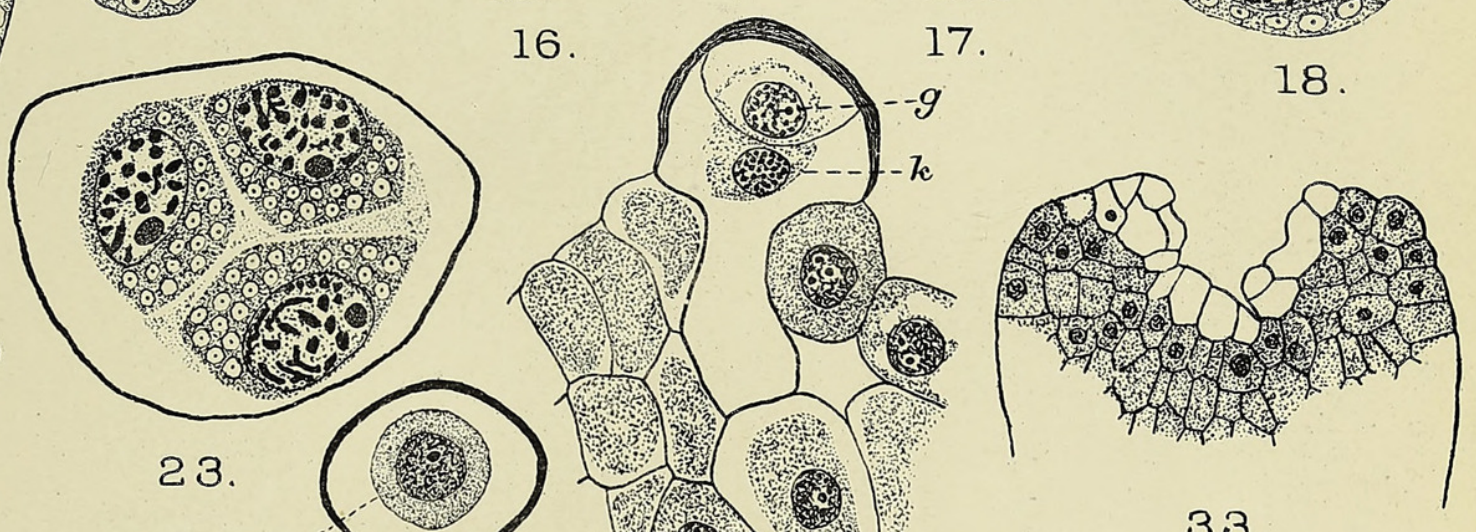

33.

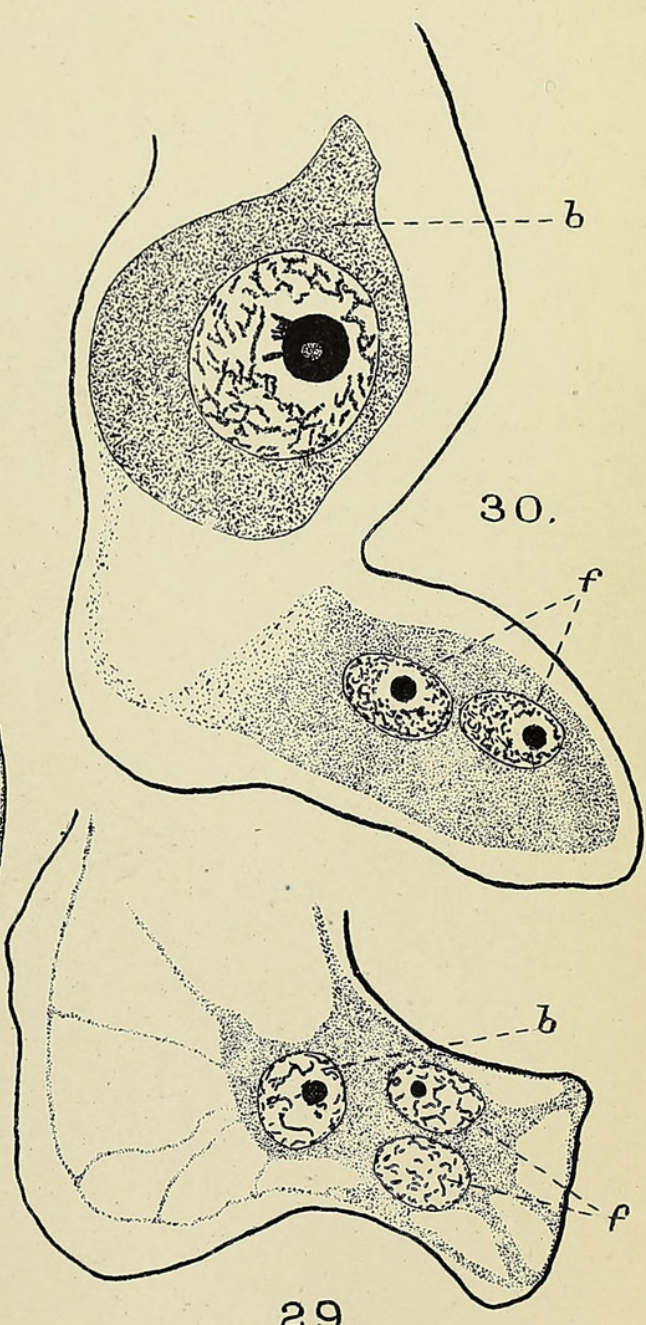

31. 


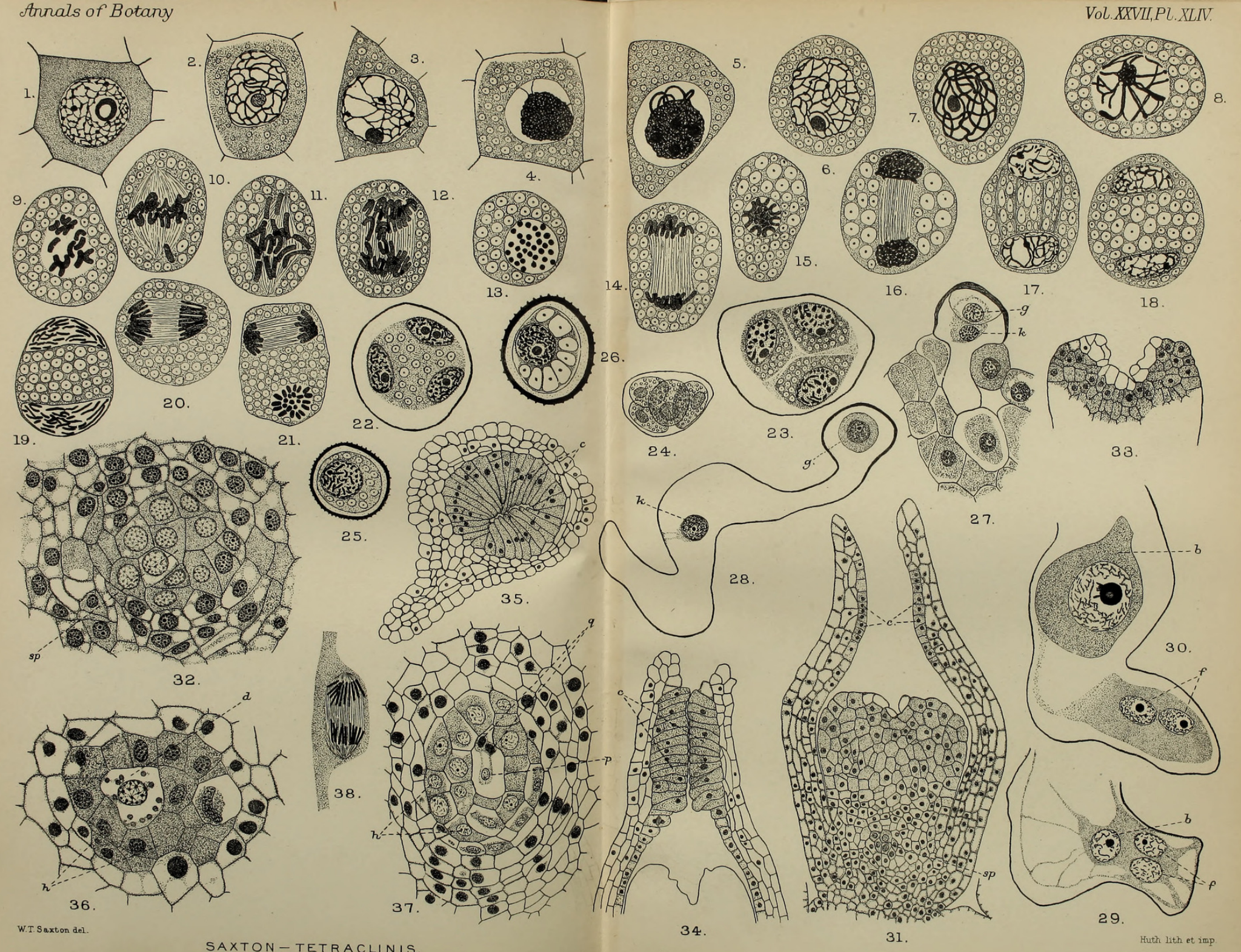


Annals of Botany
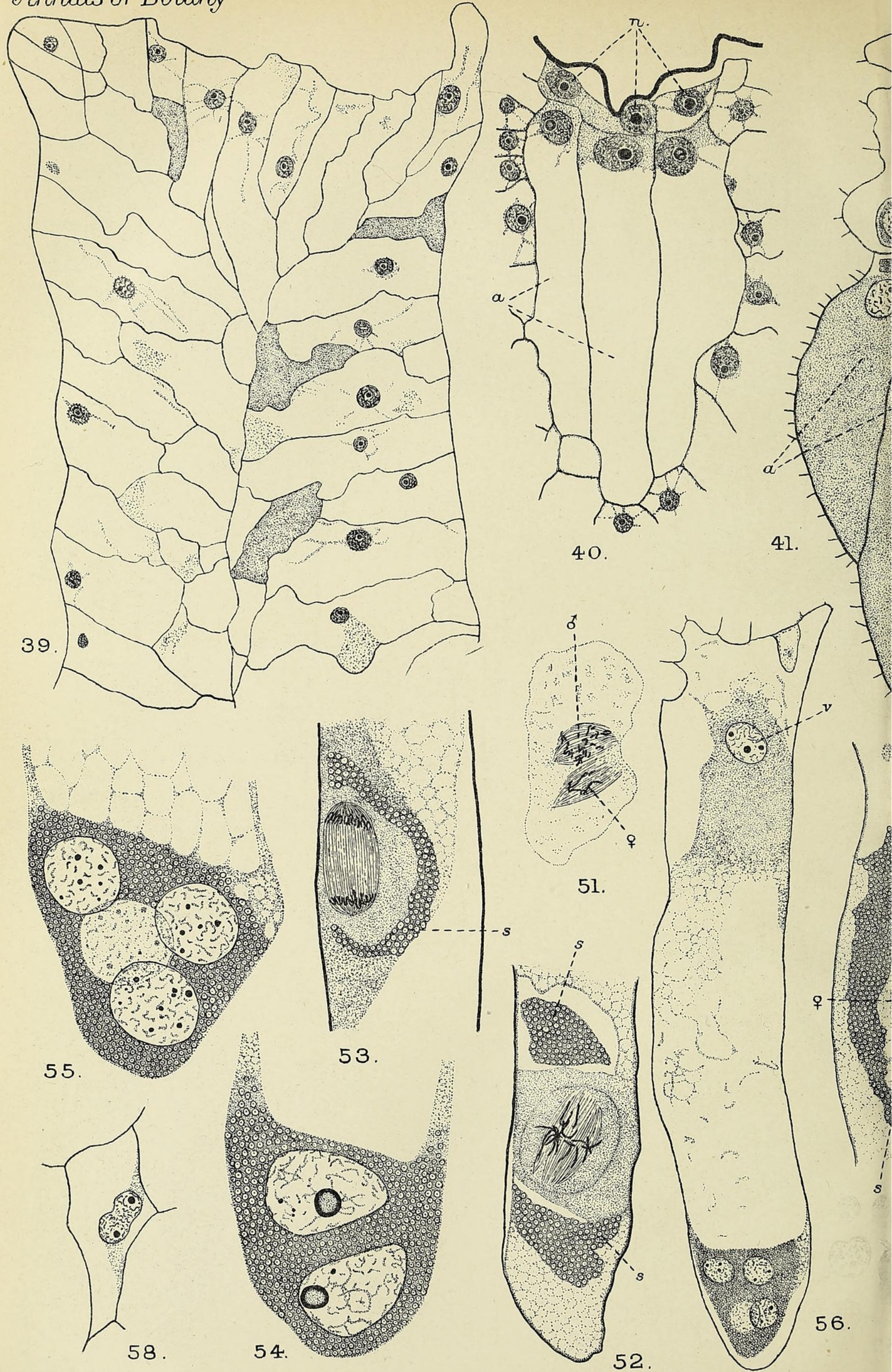

W. T. Saxtorn del. 


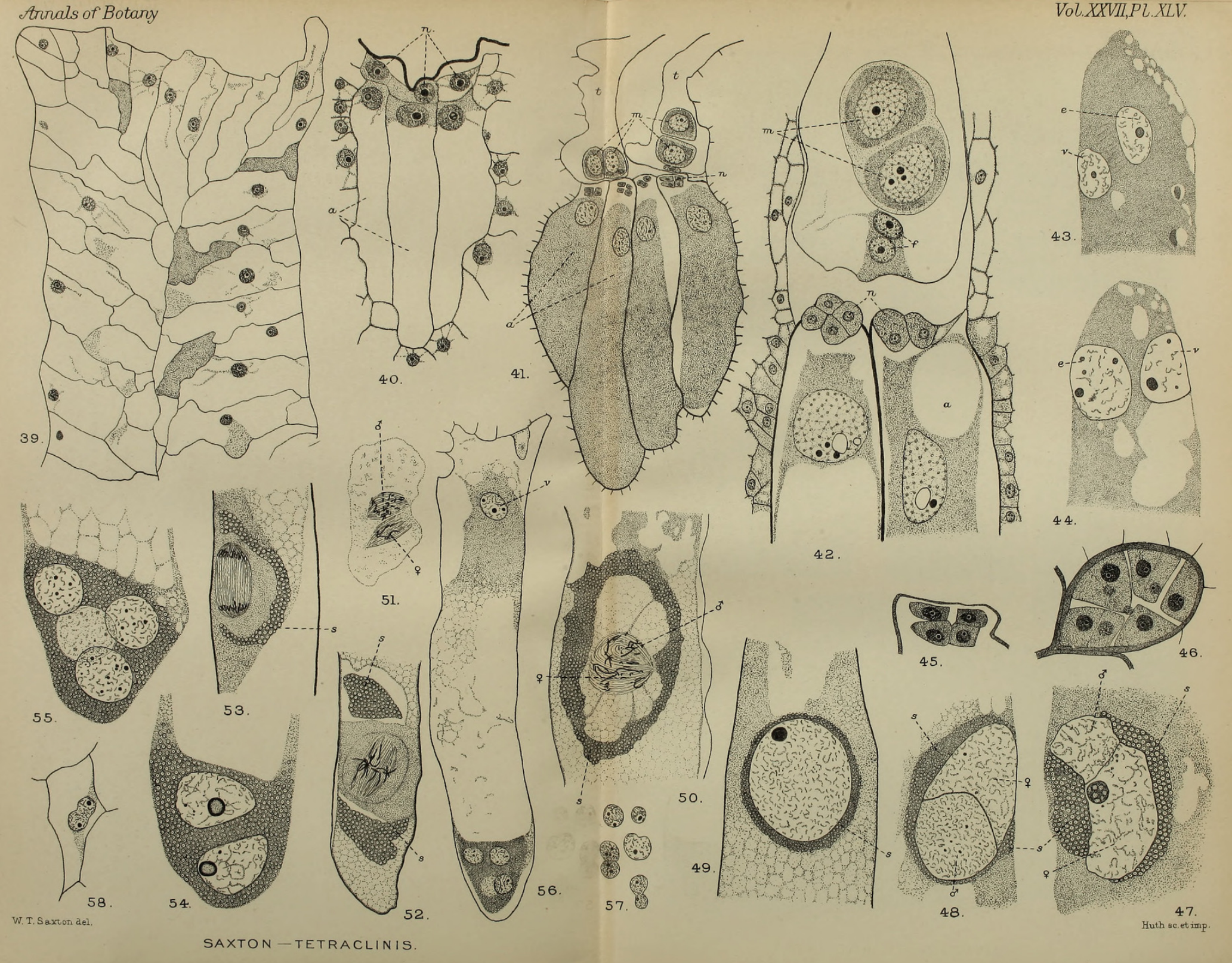




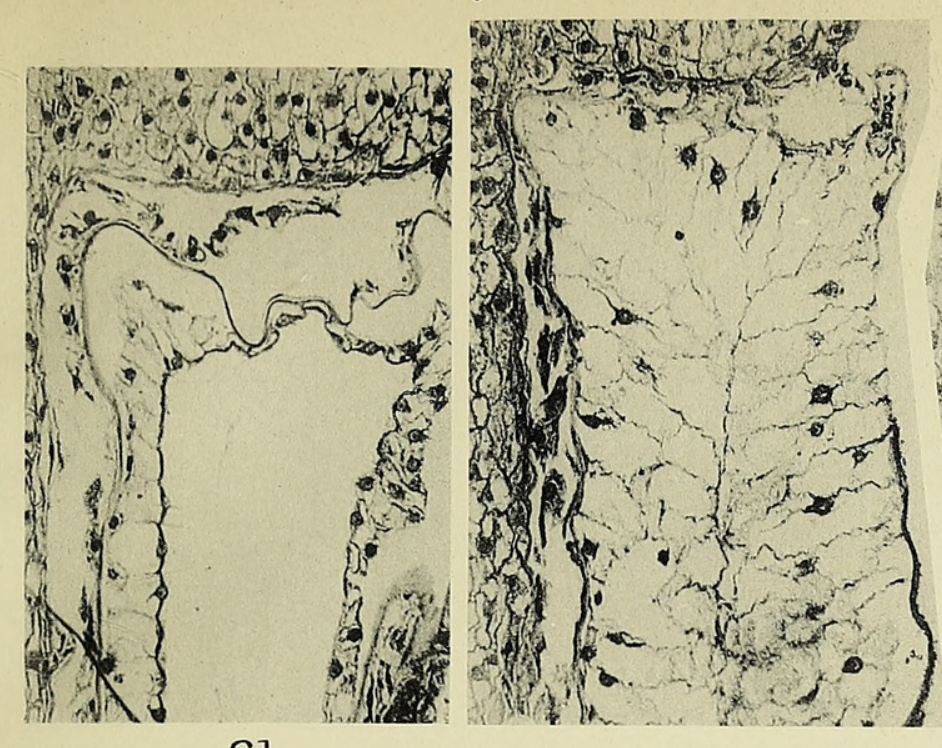

61.

62.

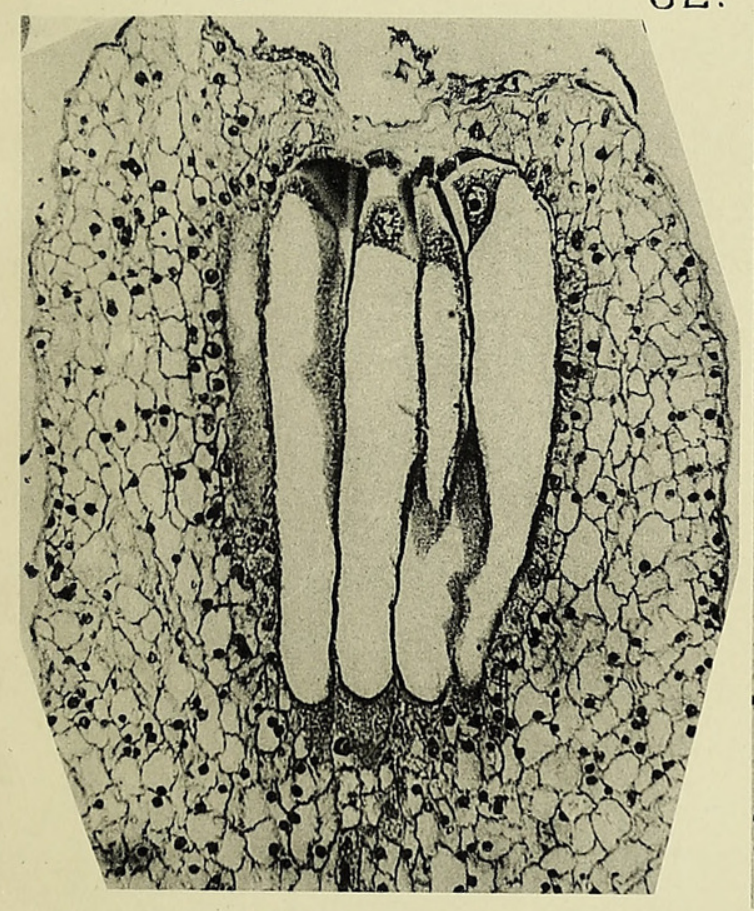

63.

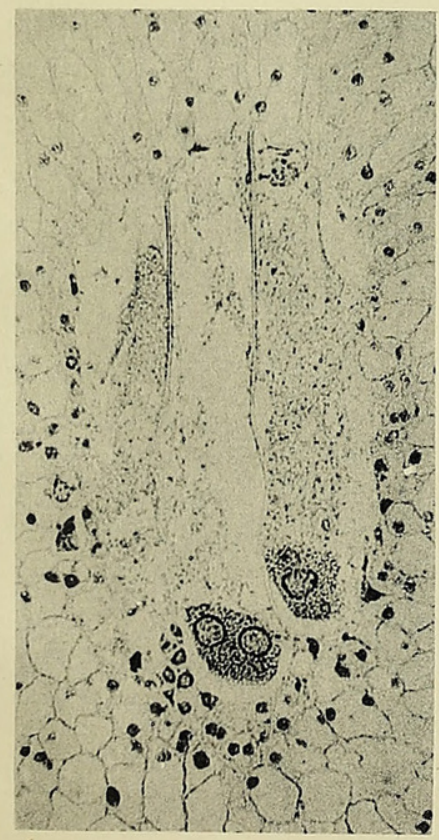

67.

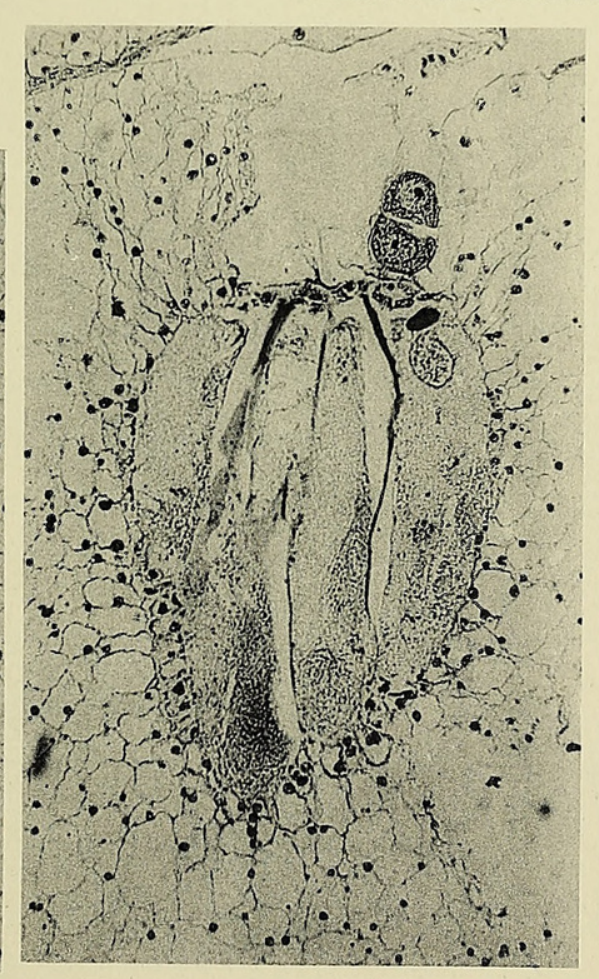

64
37. 1.

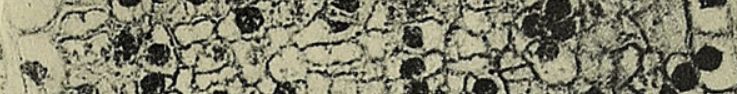

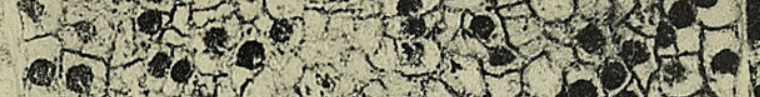
. 30.6

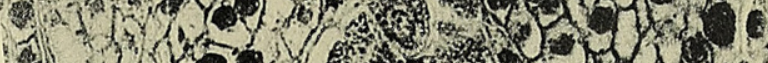
- 7. 9.7 (n)

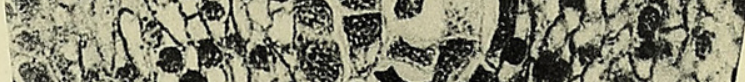

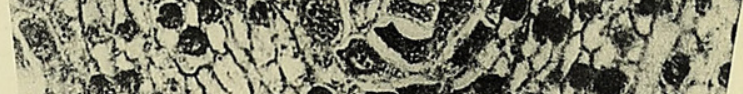
1. 01010

60
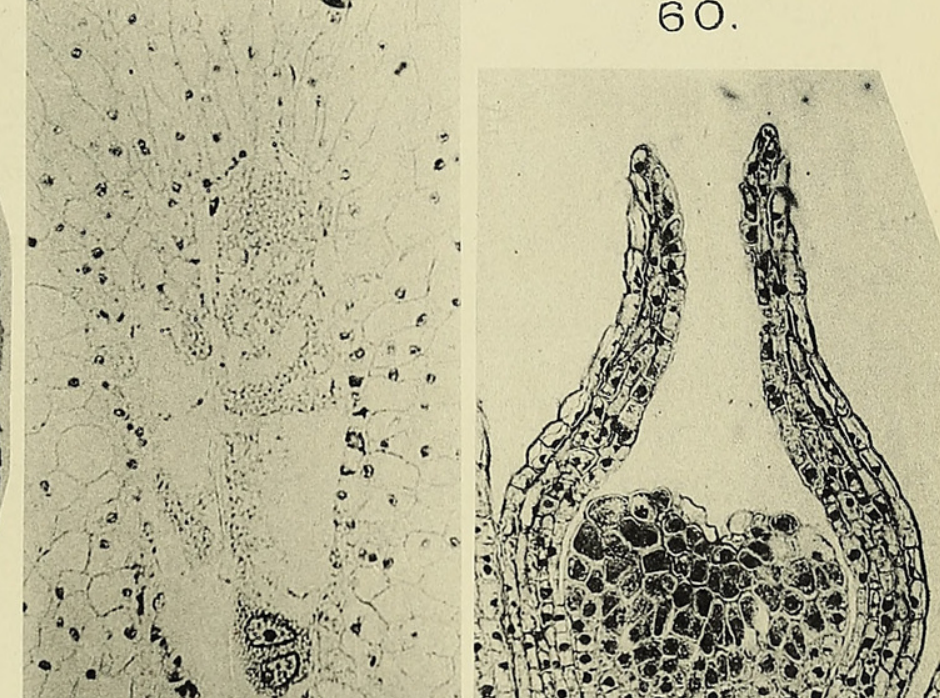

59

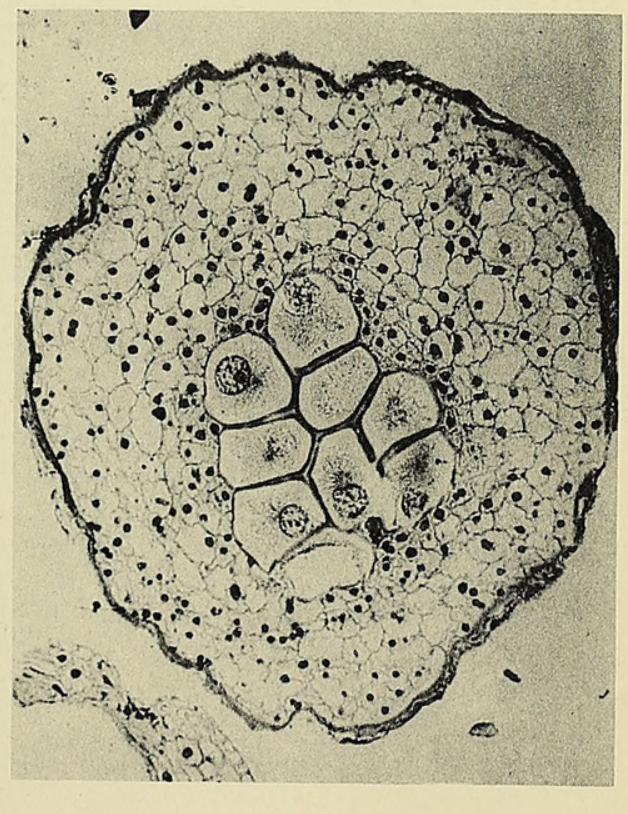

65. 


\section{$2 \mathrm{BHL}$ Biodiversity Heritage Library}

Saxton, W. T. 1913. "Contributions to the life-history of Tetraclinis articulata, Masters, with some notes on the phylogeny of the Cupressoïdeae and Callitroïdeae." Annals of botany 27, 577-605.

https://doi.org/10.1093/oxfordjournals.aob.a089478.

View This Item Online: https://www.biodiversitylibrary.org/item/237410

DOI: https://doi.org/10.1093/oxfordjournals.aob.a089478

Permalink: https://www.biodiversitylibrary.org/partpdf/319991

\section{Holding Institution}

Smithsonian Libraries

\section{Sponsored by}

Biodiversity Heritage Library

\section{Copyright \& Reuse}

Copyright Status: Not in copyright. The BHL knows of no copyright restrictions on this item.

This document was created from content at the Biodiversity Heritage Library, the world's largest open access digital library for biodiversity literature and archives. Visit BHL at https://www.biodiversitylibrary.org. 